See discussions, stats, and author profiles for this publication at: https://www.researchgate.net/publication/305706219

\title{
Survey Batimetri dan Pengamatan Kondisi Kualitas Air di Perairan Musi, Gerokgak, Bali untuk Budidaya Laut
}

Technical Report · January 2014

DOI: $10.13140 / R G .2 .1 .3817 .8802$

CITATIONS

0

5 authors, including:

Agus Setiawan

Ministry of Marine Affairs and Fisheries

48 PUBLICATIONS 66 CITATIONS

SEE PROFILE

Faisal Hamzah

Xiamen University

15 PUBLICATIONS 14 CITATIONS

SEE PROFILE

Some of the authors of this publication are also working on these related projects:

Project INDONACE View project

Project Transports, Internal Waves and Mixing in the Indonesian Throughflow region View project
3,150

Bayu Priyono

Ministry of Marine Affairs and Fisheries

11 PUBLICATIONS 6 CITATIONS

SEE PROFILE 


\section{SURVEY BATIMETRI DAN PENGAMATAN KONDISI KUALITAS AIR DI PERAIRAN MUSI, GEROKGAK, BALI UNTUK BUDIDAYA LAUT}

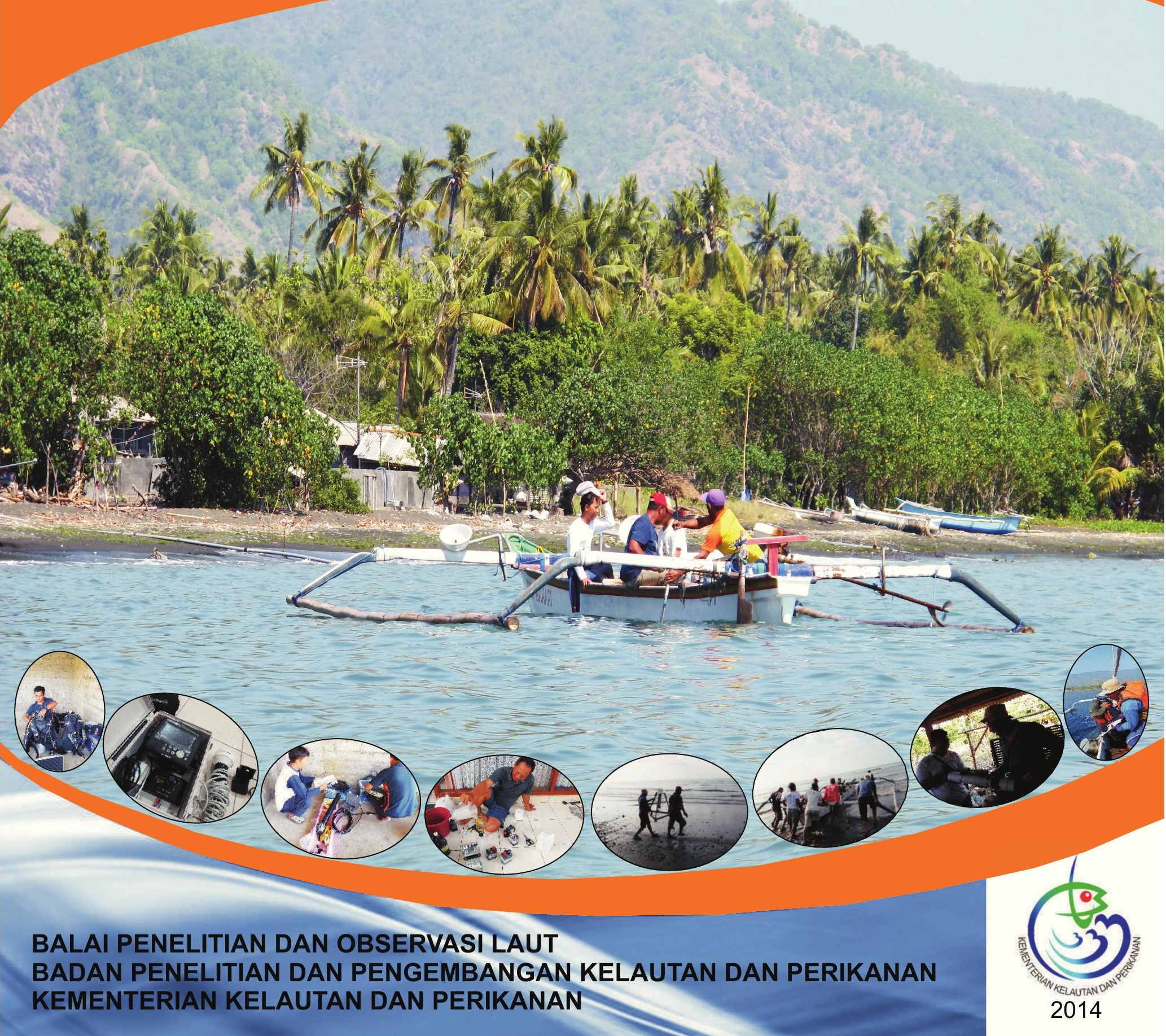




\section{LAPORAN}

SURVEY BATIMETRI DAN PENGAMATAN KONDISI KUALITAS AIR DI PERAIRAN MUSI, GEROKGAK, BALI UNTUK BUDIDAYA LAUT

Tim Penyusun

Agus Setiawan, Bayu Priyono, Faisal Hamzah,

Tedi Firmansyah, Yuli Pancawati

BALAI PENELITIAN DAN OBSERVASI LAUT

BADAN PENELITIAN DAN PENGEMBANGAN KELAUTAN DAN PERIKANAN KEMENTERIAN KELAUTAN DAN PERIKANAN

2014 


\section{DAFTAR ISI}

DAFTAR ISI $\quad 1$

DAFTAR TABEL $\quad 3$

DAFTAR GAMBAR $\quad 4$

1. PENDAHULUAN 5

2. PELAKSANAAN SURVEY

$\begin{array}{lr}\text { a. Pengukuran Batimetri } & 7\end{array}$

$\begin{array}{llr}\text { b. } & \text { Arus dan Pasang Surut Laut } & 8\end{array}$

$\begin{array}{lr}\text { c. Suhu, Salinitas, dan pH } & 8\end{array}$

$\begin{array}{llr}\text { d. } & \text { Kecerahan Perairan dan Turbiditas } & 8\end{array}$

e. Benthic Macroinvertebrate dan Benthic Soil Type $\quad 9$

f. Konsentrasi Klorofil-a dan Total Bacterial Population 9

g. Konsentrasi Ammonia, Fosfat, Total Padatan Tersuspensi (TSS), Total Padatan Terlarut (TDS) dan $\begin{array}{lr}\text { Oksigen Terlarut (DO) } & 9\end{array}$

3. ANALISIS LABORATORIUM $\quad 10$

$\begin{array}{lr}\text { a. Konsentrasi Ammonia } & 10\end{array}$

$\begin{array}{lr}\text { b. Konsentrasi Fosfat } & 10\end{array}$

$\begin{array}{lr}\text { c. Konsentrasi Klorofil-a } & 10\end{array}$

d. Konsentrasi Oksigen Terlarut (Dissolved Oxygen)

e. Total Bacterial Population $\quad 11$

f. Total Padatan Tersuspensi (Total Suspended Solid) 11

g. Total Padatan Terlarut (Total Dissolved Solid)

h. Benthic Macroinvertebrate dan Benthic Soil Type $\quad 11$

i. Analisis Sedimen Dasar $r$ 
b. Arus Laut 13

c. Pasang Surut

a. Suhu Permukaan Laut $\quad 19$

b. Oksigen Terlarut (Dissolved Oxygen) 20

$\begin{array}{ll}\text { c. Salinitas } & 21\end{array}$

d. $\mathrm{pH} \quad 22$

e. Kecerahan (Visibility) 23

f. Kekeruhan (Turbiditas) $\quad 24$

g. Benthic Macroinvertebrate dan Benthic Soil Type 25

h. Sedimen Dasar 26

$\begin{array}{lr}\text { i. Konsentrasi Klorofil-a } & 27\end{array}$

$\begin{array}{lll}\text { j. } & \text { Populasi Bakteri Total } & 28\end{array}$

k. Konsentrasi Fosfat $\left(\mathrm{PO}_{4}-\mathrm{P}\right) \quad 29$

I. Konsentrasi Ammonia $\left(\mathrm{NH}_{3}-\mathrm{N}\right) \quad 30$

m. Padatan Tersuspensi Total (Total Suspended Solid) 31

n. Padatan Terlarut Total (Total Dissolved Solid) 32

6. KESIMPULAN DAN SARAN 33

$\begin{array}{ll}\text { DAFTAR PUSTAKA } & 34\end{array}$ 


\section{DAFTAR TABEL}

Tabel 1. Daftar parameter untuk pengukuran insitu 6

Tabel 2. Daftar parameter yang dianalisis di laboratorium 6

Tabel 3. Daftar peralatan yang digunakan dalam kegiatan survey 7

Tabel 4. Posisi geografis stasiun pengukuran $\quad 10$

Tabel 5. Elevasi pasang surut di pesisir Desa Musi hasil pengukuran 17

$\begin{array}{lll}\text { Tabel 6. Tipe pasang surut berdasarkan bilangan Formzahl (F) } & 17\end{array}$

Tabel 7. Elevasi acuan untuk perairan pesisir Gondol dan sekitarnya 18

Tabel 8. Baku mutu air laut untuk biota laut berdasarkan Kepmen LH No. 51 Tahun 200419

Tabel 9. Kepadatan bentos di sedimen perairan Desa Musi Kabupaten Buleleng, Bali 26

Tabel 10. Persentase komposisi ukuran butiran sedimen pada Stasiun $1-4 \quad 27$

Tabel 11. Populasi bakteri total di perairan Desa Musi Kabupaten Buleleng, Bali 28 


\section{DAFTAR GAMBAR}

Gambar 1. Lokasi titik pengukuran dan pengambilan sampel air 5

Gambar 2. Kondisi pasang surut pada saat pengukuran 5

$\begin{array}{lll}\text { Gambar 3. } & \text { Rencana lajur pengukuran batimetri } & 7\end{array}$

Gambar 4. Kontur kedalaman perairan di pesisir Desa Musi, Kecamatan Gerokgak,

Kabupaten Buleleng, Bali. Titik abu-abu adalah titik pemeruman sementara garis lurus utara-selatan dari daratan (tanah) adalah garis transek untuk penggambaran irisan profil kedalaman 12

Gambar 5. Peta batimetri perairan di pesisir Desa Musi, Kecamatan Gerokgak, Kabupaten

Buleleng, Bali 13

Gambar 6. Irisan profil kedalaman pada garis transek arah utara calon lokasi budidaya 13

Gambar 7. Grafik kecepatan arus pada kedalaman 0 - 5 meter 14

Gambar 8. Grafik kecepatan arus pada kedalaman 6-10 meter 14

Gambar 9. Grafik kecepatan arus pada kedalaman 11 - 15 meter 14

Gambar 10. Grafik kecepatan arus pada kedalaman 16 - 20 meter 15

Gambar 11. Grafik kecepatan arus pada kedalaman 21-25 meter 15

Gambar 12. Mawar arus di perairan Desa Musi, Kecamatan Gerokgak, Kabupaten

Buleleng, Bali 16

Gambar 13. Pasang surut di perairan Desa Musi, Kabupaten Buleleng bulan Agustus 2014

Gambar 14. Hasil pengukuran suhu permukaan laut di Stasiun 1 - 4 Perairan Desa Musi,

Kabupaten Buleleng, Bali 20

Gambar 15. Hasil pengukuran oksigen terlarut di Stasiun 1 - 4 Perairan Desa Musi, Kabupaten Buleleng, Bali

Gambar 16. Hasil pengukuran salinitas di Stasiun 1 - 4 Perairan Desa Musi, Kabupaten Buleleng, Bali

Gambar 17. Hasil pengukuran pH di Stasiun 1 - 4 Perairan Desa Musi, Kabupaten Buleleng, Bali

Gambar 18. Hasil Pengukuran Kecerahan di Stasiun 1 - 4 Perairan Desa Musi, Kabupaten Buleleng, Bali

Gambar 19. Hasil pengukuran turbiditas di Stasiun 1-4 Perairan Desa Musi, Kabupaten Buleleng, Bali

Gambar 20. Konsentrasi klorofil-a di Stasiun 1 - 4 Perairan Desa Musi Kabupaten Buleleng, Bali

Gambar 21. Konsentrasi fosfat di Stasiun 1 - 4 Desa Musi, Kabupaten Buleleng, Bali 29

Gambar 22. Kadar Ammonia di Stasiun 1-4 Desa Musi, Kabupaten Buleleng, Bali 30

Gambar 23. Hasil pengukuran padatan tersuspensi total (TSS) di Stasiun 1 - 4 Perairan Desa Musi, Kabupaten Buleleng, Bali 32

Gambar 24. Hasil pengukuran padatan terlarut total (TDS) di Stasiun 1 - 4 Perairan Desa Musi, Kabupaten Buleleng, Bali 


\section{PENDAHULUAN}

Dalam rangka mempersiapkan kegiatan budidaya laut yang akan dilakukan di Perairan Musi terlebih dahulu perlu dilakukan survey pendahuluan untuk mengetahui kondisi batimetri dan kualitas perairan di lokasi budidaya yang direncanakan tersebut. Hal ini perlu dilakukan agar kondisi perairan yang nantinya dipilih sebagai lokasi budidaya memang benar-benar sesuai dan memenuhi syarat untuk kegiatan budidaya.

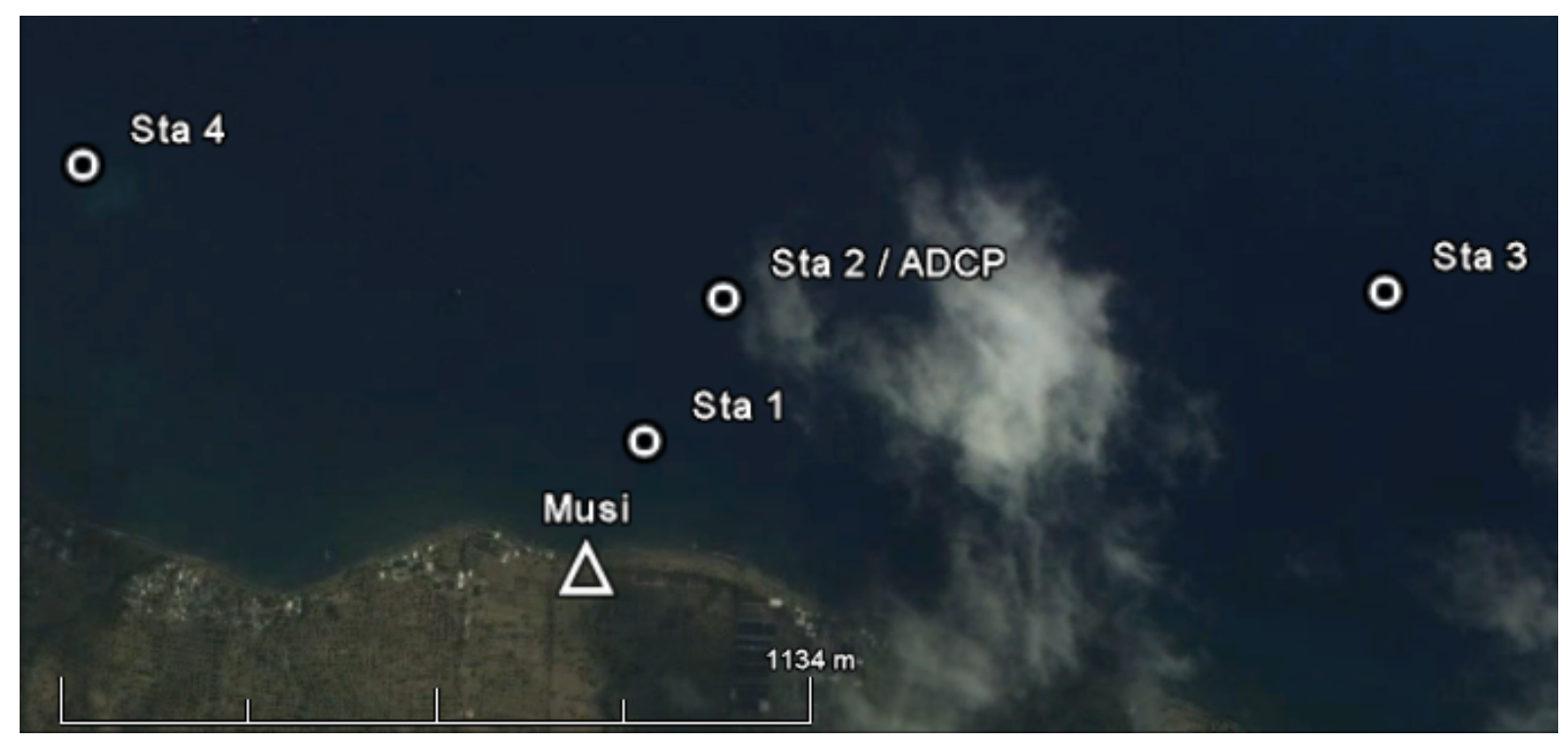

Gambar 1. Lokasi titik pengukuran dan pengambilan sampel air

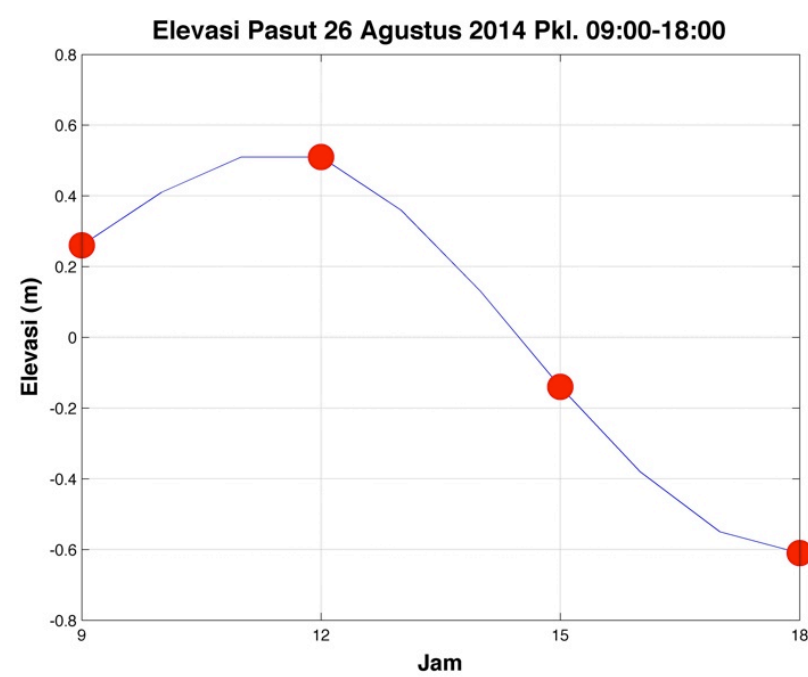

Gambar 2. Kondisi pasang surut pada saat pengukuran

Survei lapangan di perairan Desa Musi, Kecamatan Gerokgak, Kabupaten Buleleng, Bali dilaksanakan pada tanggal 25 - 28 Agustus 2014, yang mencakup survey batimetri dan pengukuran langsung (insitu) serta pengambilan sampel untuk keperluan analisis di 
laboratorium (exsitu) beberapa parameter oseanografi yang penting dalam kegiatan budidaya laut. Parameter-parameter tersebut diukur pada empat lokasi pengamatan (lihat Gambar 1) pada empat waktu pasang surut yang berbeda, yaitu saat surut menuju pasang, pasang tertinggi, pasang menuju surut dan surut terendah, yang secara berurutan terwakili pada pukul 09.00, 12.00, 15.00 dan 18.00 WITA tanggal 26 Agustus 2014 (lihat Gambar 2).

Parameter kualitas air laut yang diukur secara insitu adalah suhu, $\mathrm{pH}$, oksigen terlarut, salinitas, turbiditas, dan kecerahan air laut, sementara itu parameter yang diukur secara exsitu (melalui analisis laboratorium di Laboratorium Proling IPB dan Laboratorium Kualitas Perairan BPOL) adalah total populasi bakteri, padatan tersuspensi total, padatan terlarut total, dan konsentrasi ammonia, fosfat, dan klorofil-a). Sementara itu, khusus untuk kepadatan bentos dan fraksi sedimen, sampel hanya diambil pada satu waktu saja karena variasinya diperkirakan tidak terlalu berubah secara signifikan terhadap pasang surut (lihat Tabel 1 dan Tabel 2). Adapun peralatan yang digunakan dalam kegiatan survey diberikan pada Tabel 3.

Dari hasil survey ini diharapkan akan dapat diperoleh gambaran awal kondisi oseanografi dan kualitas air di perairan Musi, Gerokgak, Bali yang selanjutnya dapat digunakan untuk perencanaan awal kegiatan budidaya laut oleh PT. Paramount Fishery Indonesia.

Tabel 1. Daftar parameter untuk pengukuran insitu

\begin{tabular}{cll}
\hline No. & \multicolumn{1}{c}{ Parameter } & \multicolumn{1}{c}{ Keterangan } \\
\hline 1. & Salinitas air laut & diukur di 4 stasiun selama satu siklus pasang surut (24 jam) \\
2. & Temperatur air laut & \\
3. & $\mathrm{pH}$ & \\
\hline
\end{tabular}

Tabel 2. Daftar parameter yang dianalisis di laboratorium

\begin{tabular}{|c|c|c|}
\hline No. & Parameter & Keterangan \\
\hline 1. & Klorofil-a* & \multirow{9}{*}{$\begin{array}{l}\text { sampel diambil di } 4 \text { stasiun pada } 4 \text { waktu yang berbeda, } \\
\text { yaitu pada saat surut minimum, menuju pasang, pasang } \\
\text { maksimum, dan menuju surut }\end{array}$} \\
\hline 2. & Oksigen terlarut (DO)* & \\
\hline 3. & Turbiditas* & \\
\hline 4. & Total padatan tersuspensi (TSS)* & \\
\hline 5. & Total Dissolved Solid (TDS)* & \\
\hline 6. & Kecerahan (Secchi disk) & \\
\hline 7. & Fosfat* & \\
\hline 8. & Ammonia* & \\
\hline 9. & Total bacterial population** & \\
\hline 10. & Benthic macroinvertebrate** & \multirow{2}{*}{$\begin{array}{l}\text { sampel diambil di } 4 \text { stasiun hanya pada satu waktu tertentu } \\
\text { saja, yaitu saat surut minimum }\end{array}$} \\
\hline 11. & Benthic soil type (5 fraksi)** & \\
\hline
\end{tabular}


Tabel 3. Daftar peralatan yang digunakan dalam kegiatan survey

\begin{tabular}{cll}
\hline No. & \multicolumn{1}{c}{ Peralatan } & \multicolumn{1}{c}{ Keterangan } \\
\hline 1. & GPS Map Fishnder + Tranducer Garmin & Untuk mengukur kedalaman (batimetri) \\
2. & Accoustic Doppler Current Profiler & $\begin{array}{l}\text { Untuk mengukur arus laut dan elevasi } \\
\text { pasang surut }\end{array}$ \\
& NORTEK Aquadopp & Untuk mengukur pH air laut \\
3. & pH meter WTW pH-3310 & Untuk mengukur salinitas air laut \\
4. & Salinometer EUTECH Salt 6+ & Untuk mengukur pH, suhu, dan salinitas air \\
5. & Water Quality Checker (WQC) TOA-DKK & laut \\
& WQC-24 & Untuk mengambil sampel air \\
6. & Nansen Water Sampler & Untuk mengukur kecerahan perairan \\
7. & Secchi Disk & Untuk pengambilan sampel sedimen \\
8. & Ekman Grab & Untuk mengukur turbiditas \\
\hline 9. & Turbidimeter TOA-DKK TB-31 & \\
\hline
\end{tabular}

\section{PELAKSANAAN SURVEY}

\section{a. Pengukuran Batimetri}

Pengukuran batimetri dilakukan untuk memperoleh informasi tentang profil kedalaman perairan di daerah kajian. Rencana pengukuran batimetri pada pekerjaan ini dilakukan dengan lajur sebagaimana ditunjukkan oleh Gambar 3.

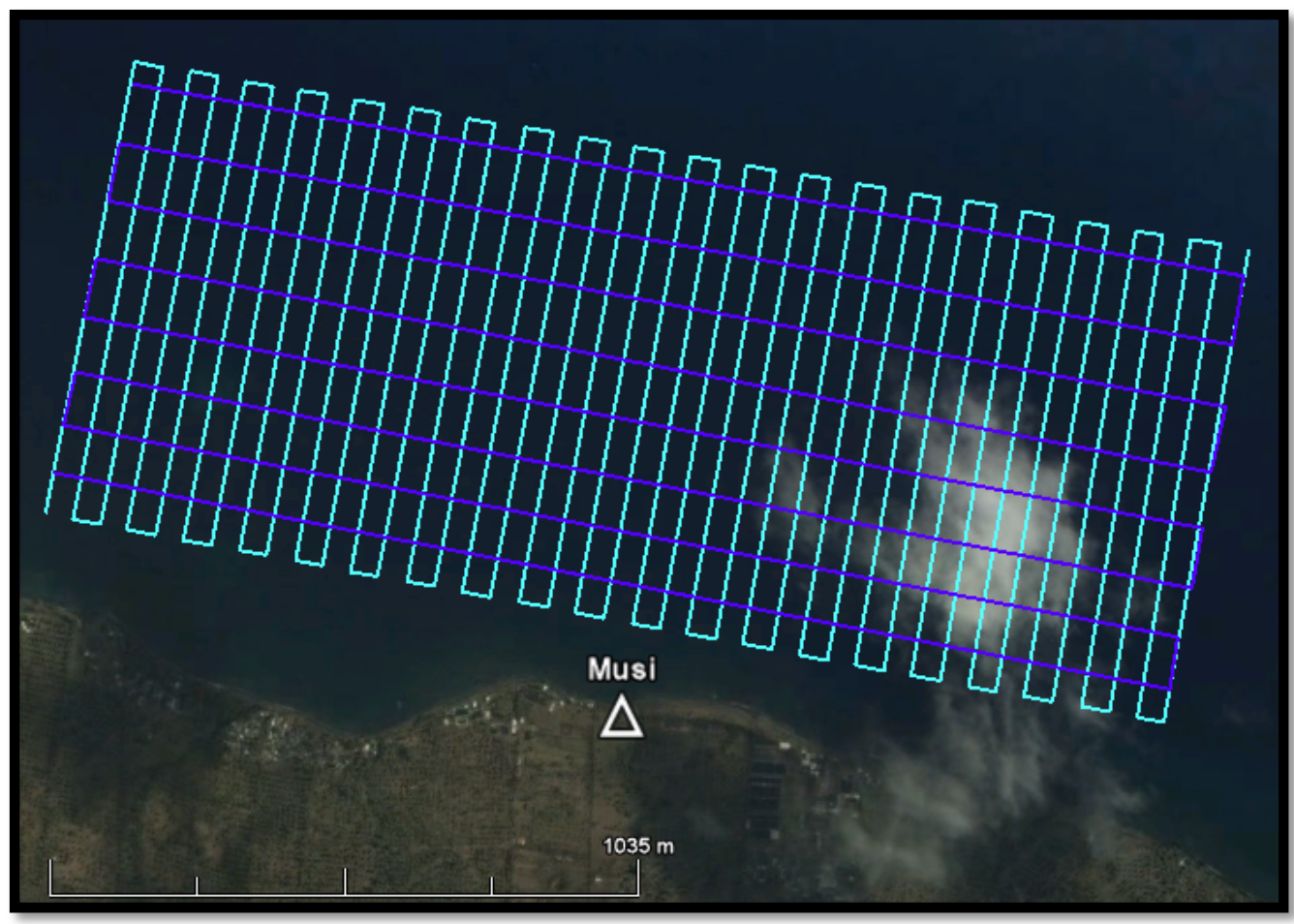

Gambar 3. Rencana lajur pengukuran batimetri 


\section{b. Arus dan Pasang Surut Laut}

Pengamatan arus laut dilakukan dengan menempatkan alat pengukur arus di dasar perairan pada titik yang dianggap mewakili pola arus di daerah kajian. Data yang diperoleh dari pengukuran arus adalah kecepatan dan arah arus di titik pengamatan pada beberapa kedalaman. Pada pekerjaan ini pengukuran arus laut dilakukan dengan instrumen ADCP (Acoustic Doppler Current Profiler). Pengukuran arus laut dan pasang surut dilakukan selama 2 hari dengan interval 10 menit dimana rentang waktu ini dimaksudkan agar diperoleh data arus pada kondisi pasang tinggi (spring tide) dan pasang rendah (neap tide). Titik lokasi pengukuran arus laut diperlihatkan pada Gambar 1.

\section{c. Suhu, Salinitas, dan $\mathrm{pH}$}

Pengamatan suhu, salinitas, dan $\mathrm{pH}$ dilakukan pada titik-titik tertentu (untuk selanjutnya titik-titik ini disebut dengan stasiun pengamatan) yang dianggap dapat mewakili distribusi suhu dan salinitas daerah kajian. Pengukuran suhu, salinitas, dan $\mathrm{pH}$ dilakukan dengan menggunakan instrumen alat $\mathrm{pH}$ meter WTW pH-3310, salinometer EUTECH Salt 6+ dan Water Quality Checker (WQC) TOA-DKK WQC-24 (lihat Tabel 3). Data yang diperoleh adalah data suhu, salinitas, dan $\mathrm{pH}$ pada stasiun pengamatan di kedalaman tertentu pada empat kondisi pasang surut yang berbeda (pasang tertinggi, pasang menuju surut, surut terendah, dan surut menuju pasang). Kondisi pasang surut pada saat pengukuran diperlihatkan pada Gambar 2, sementara lokasi stasiun pengamatan diperlihatkan pada Gambar 1.

\section{d. Kecerahan Perairan dan Turbiditas}

Pengamatan kecerahan perairan dilakukan untuk mengetahui tingkat penetrasi cahaya matahari pada suatu kolom air. Pengukuran kecerahan perairan dilakukan pada stasiun pengamatan dengan menggunakan instrumen Secchi disk. Sementara itu pengukuran turbiditas atau kekeruhan kolom air dilakukan melalui analisis di laboratorium terhadap sampel air yang diambil. Pengukuran kecerahan perairan dan pengambilan sampel air untuk analisis turbiditas dilakukan di semua stasiun pengamatan (lihat Gambar 1) dan pada empat kondisi pasang surut yang berbeda (pasang tertinggi, pasang menuju surut, surut terendah, dan surut menuju pasang) (lihat Gambar 2). 


\section{e. Benthic Macroinvertebrate dan Benthic Soil Type}

Sampel sedimen perairan diambil menggunakan Ekman grab, dimana sedimen yang diperoleh dianalisis di laboratorium untuk mendapatkan data sedimen dasar, benthic macroinvertebrate dan benthic soil type.

Benthic macroinvertebrate merupakan hewan kecil tidak bertulang belakang yang hidup di dasar perairan dan dapat dilihat dengan mata. Contoh dari benthic macroinvertebrate di dasar perairan laut adalah jenis siput, kerang, cacing, dan udang. Kelompok organisme ini berperan penting dalam rantai makanan di lingkungan perairan. Selain itu benthic macroinvertebrate juga berperan penting dalam pengolahan dan daur nutrisi dan merupakan sumber makanan utama bagi ikan dan hewan air lainnya. Berbeda dengan pengambilan sampel parameter lainnya, sampel benthic macroinvertebrate dan benthic soil type diambil di semua stasiun hanya pada satu waktu tertentu saja, yaitu saat surut minimum.

\section{f. Konsentrasi Klorofil-a dan Total Bacterial Population}

Pengukuran konsentrasi klorofil-a dan total bacterial population dilakukan untuk mengetahui tingkat kesuburan suatu perairan. Nilai konsentrasi klorofil-a dan total bacterial population ini diperoleh dari hasil analisis di laboratorium terhadap sampel air laut yang diambil di semua stasiun pengamatan.

\section{g. Konsentrasi Ammonia, Fosfat, Total Padatan Tersuspensi (TSS), Total Padatan Terlarut (TDS) dan Oksigen Terlarut (DO)}

Parameter kimia dan fisika lainnya yang diukur dalam kegiatan ini adalah ammonia, fosfat, total padatan tersuspensi (TSS), total padatan terlarut (TDS), dan Oksigen terlarut (DO). Seluruh parameter tersebut diukur di setiap stasiun pengamatan di kedalaman tertentu pada empat kondisi pasang surut yang berbeda. Lokasi stasiun pengamatan parameter kimia dan fisik ini diperlihatkan pada Gambar 1.

Pengambilan sampel air dilakukan dengan menggunakan Nansen Water Sampler dengan volume 4 liter. Saat Nansen water sampler tiba di permukaan, maka dengan segera dilakukan analisis oksigen terlarut (dissolved oxygen/DO). Analisis DO mengacu pada metode titrasi Winkler, dimana volume $\mathrm{Na}_{2} \mathrm{SO}_{3}$ yang digunakan dalam titrasi sebanding 
dengan kadar oksigen terlarut. Koordinat posisi geografis dari titik pengamatan arus laut dan stasiun pengamatan parameter kimia dan biologi lainnya diperlihatkan pada Tabel 1 .

Tabel 4. Posisi geografis stasiun pengukuran

\begin{tabular}{cccc}
\hline \multirow{2}{*}{ ID Stasiun } & \multirow{2}{*}{$\begin{array}{c}\text { Kedalaman } \\
(\mathbf{m})\end{array}$} & Lintang & Posisi \\
\cline { 3 - 4 } & 14,0 & $8^{\circ} 10^{\prime} 03,4^{\prime \prime} \mathrm{LS}$ & $114^{\circ} 45^{\prime} 20,8^{\prime \prime} \mathrm{BT}$ \\
Sta 1 & 28,8 & $8^{\circ} 09^{\prime} 56,6^{\prime \prime} \mathrm{LS}$ & $114^{\circ} 45^{\prime} 25,1^{\prime \prime} \mathrm{BT}$ \\
Sta 2/ADCP & 32,5 & $8^{\circ} 09^{\prime} 56,7^{\prime \prime} \mathrm{LS}$ & $114^{\circ} 45^{\prime} 57,7^{\prime \prime} \mathrm{BT}$ \\
Sta 3 & 20,5 & $8^{\circ} 09^{\prime} 49,6^{\prime \prime} \mathrm{LS}$ & $114^{\circ} 44^{\prime} 53,1^{\prime \prime} \mathrm{BT}$ \\
\hline Sta 4 & & & \\
\hline
\end{tabular}

\section{ANALISIS LABORATORIUM}

\section{a. Konsentrasi Ammonia}

Standar yang digunakan untuk melakukan uji konsentrasi ammonia adalah mengacu pada metode SNI 06-6989.30-2005. Cara uji ini digunakan untuk penentuan konsentrasi ammonia dengan spektrofotometer secara fenat dalam contoh air dan air limbah pada kisaran kadar 0,1 mg/L sampai dengan 0,6 mg/L NH3-N pada panjang gelombang $640 \mathrm{~nm}$.

\section{b. Konsentrasi Fosfat}

Standar yang digunakan untuk melakukan uji konsentrasi fosfat adalah mengacu pada metode SNI 06-6989.31-2005. Cara uji ini digunakan untuk penentuan konsentrasi fosfat dengan spektrofotometer secara asam askorbat dalam contoh air dan air limbah pada kisaran kadar 0,01mg P/L sampai dengan 1,0 mg P/L pada panjang gelombang $880 \mathrm{~nm}$.

\section{c. Konsentrasi Klorofil-a}

Standar yang digunakan untuk melakukan uji konsentrasi klorofil-a adalah mengacu pada metode APHA 10200. Cara uji ini digunakan untuk penentuan konsentrasi klorofil-a dengan menyaring air laut sebanyak 4 liter dengan kertas saring millipore berukuran diameter $0,45 \mu \mathrm{m}$, kemudian melarutkan kertas saring tersebut dalam aseton p.a. dengan teknik sentrifugasi. Larutan supernatan selanjutnya dianalisis menggunakan spektrofotometer pada panjang gelombang 630, 647, 664 dan $750 \mathrm{~nm}$. 


\section{d. Konsentrasi Oksigen Terlarut (Dissolved Oxygen)}

Standar yang digunakan untuk melakukan uji konsentrasi oksigen terlarut (DO) adalah mengacu pada metode titrasi Winkler.

\section{e. Total Bacterial Population}

Standar yang digunakan untuk mengetahui nilai total bacterial population adalah dengan metode deteksi limit.

\section{f. Total Padlatan Tersuspensi (Total Suspended Solid)}

Standar yang digunakan untuk mengetahui nilai Total Padatan Tersuspensi (TSS) adalah mengacu pada metode SNI 06-6989.3-2004.

\section{g. Total Padatan Terlarut (Total Dissolved Solid)}

Standar yang digunakan untuk mengetahui nilai Total Padatan Terlarut (TDS) adalah mengacu pada metode SNI 06-6989.27-2005.

\section{h. Benthic Macroinvertebrate dan Benthic Soil Type}

Standar yang digunakan untuk mengetahui jenis dari benthic microinvertebrate dan benthic soil type pada pekerjaan ini adalah dengan metode pencacahan (sensus).

\section{i. Analisis Sedimen Dasar}

Metode analisis sedimen yang digunakan adalah metode pipet.

\section{HASIL SURVEY KONDISI FISIS}

\section{a. Batimetri}

Peta batimetri pada laporan ini merupakan hasil interpolasi spasial dari titik-titik pemeruman (sounding) pada survey batimetri di pesisir Desa Musi, Kecamatan Gerokgak, Bali. Sebelum dilakukan interpolasi, kedalaman yang diperoleh dari hasil pemeruman dikoreksi terhadap dahulu terhadap elevasi pasang surut sesaat. Hal ini perlu dilakukan agar kedalaman pada peta batimetri yang dihasilkan mempunyai acuan elevasi permukaan laut yang sama. Pada laporan ini, kedalaman perairan yang tertera pada peta batimetri 
mengacu pada kondisi muka air laut surut terendah (Lowest Water Level atau LWL). Gambar kontur kedalaman dan peta batimetri di lokasi kajian hasil survey diperlihatkan pada Gambar 4 dan Gambar 5.

Dari data batimetri tersebut dapat dilihat bahwa perairan di pesisir Desa Musi mempunyai dasar perairan yang cukup landai dari kedalaman $25 \mathrm{~m}$ hingga $45 \mathrm{~m}$. Dari pantai hingga kedalaman $25 \mathrm{~m}$, kemiringan dasar perairan cenderung lebih curam dimana hal ini dapat dilihat dari garis kontur $0-25 \mathrm{~m}$ yang lebih rapat daripada garis kontur pada kedalaman yang lebih besar. Secara keseluruhan daerah kajian merupakan perairan yang cenderung landai dan dangkal dimana kedalaman maksimal yang terukur pada saat pelaksanaan survey adalah $50,8 \mathrm{~m}$.

Untuk memperlihatkan profil kedalaman perairan secara dua dimensi, di sebelah utara tanah kegiatan budidaya dibuat transek irisan melintang sepanjang batas area survey. Posisi transek melintang diperlihatkan oleh garis lurus pada Gambar 4. Irisan profil kedalaman pada garis transek dapat dilihat pada Gambar 6.

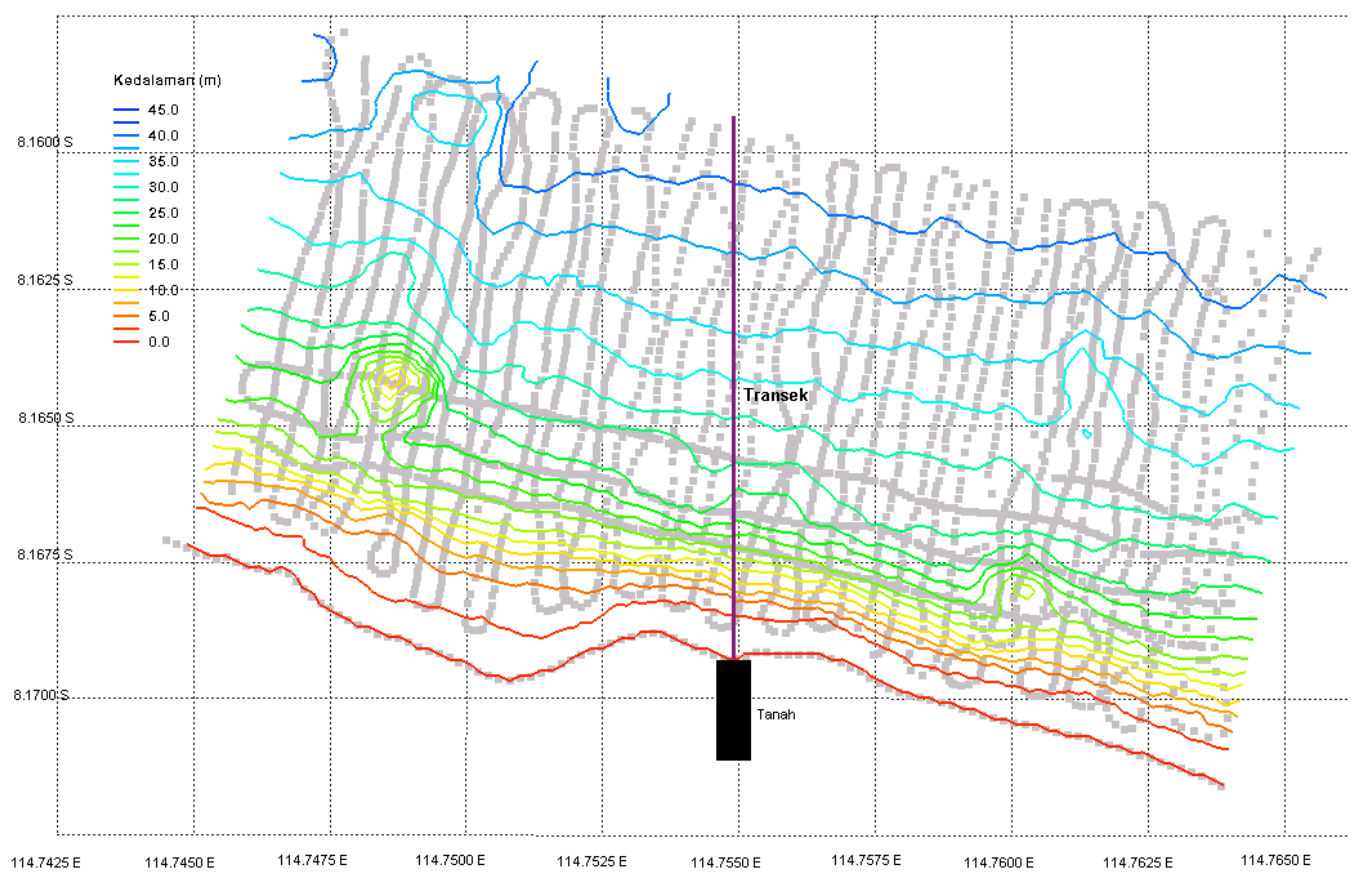

Gambar 4. Kontur kedalaman perairan di pesisir Desa Musi, Kecamatan Gerokgak, Kabupaten Buleleng, Bali. Titik abu-abu adalah titik pemeruman sementara garis lurus utara-selatan dari daratan (tanah) adalah garis transek untuk penggambaran irisan profil kedalaman 


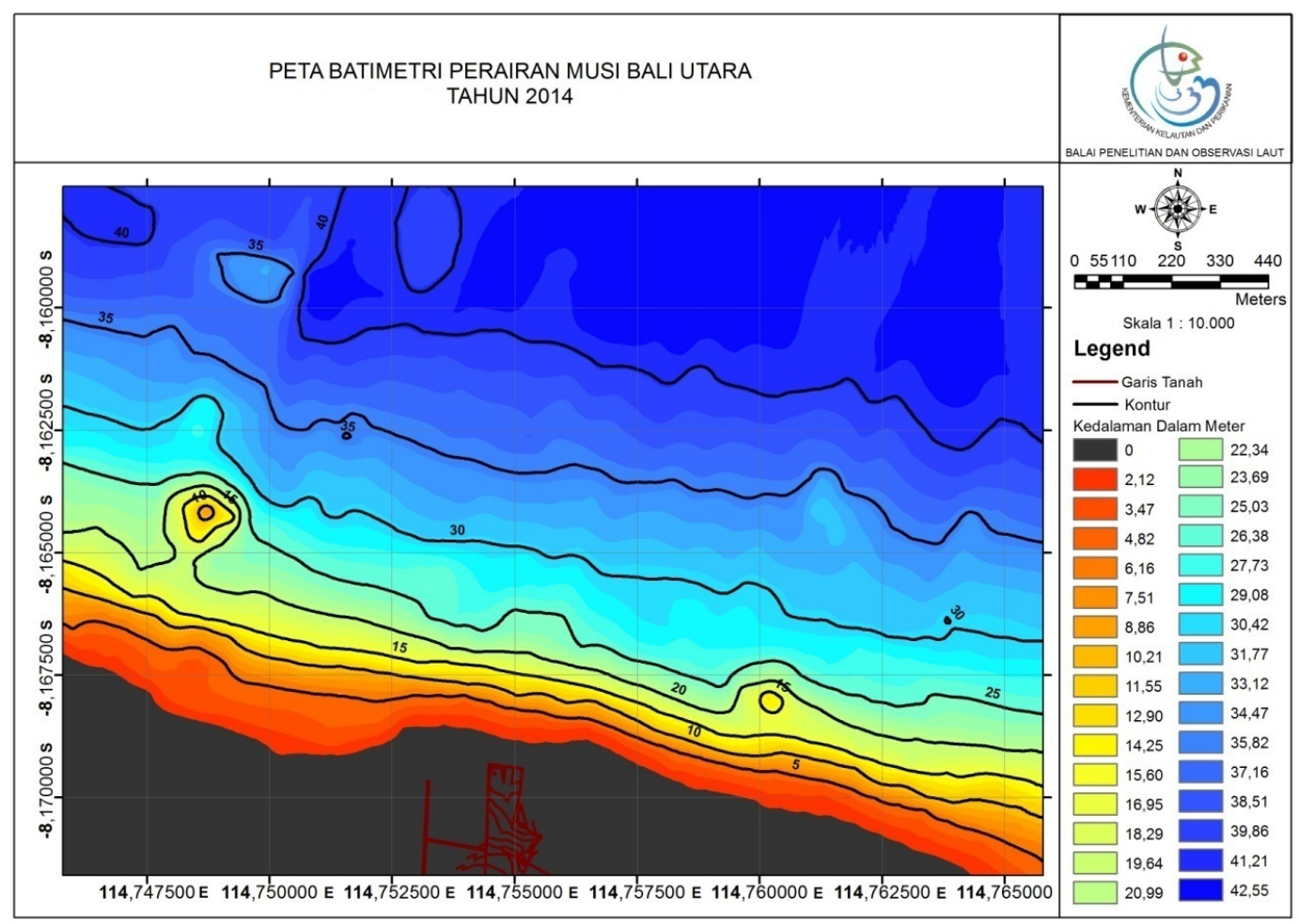

Gambar 5. Peta batimetri perairan di pesisir Desa Musi, Kecamatan Gerokgak, Kabupaten Buleleng, Bali

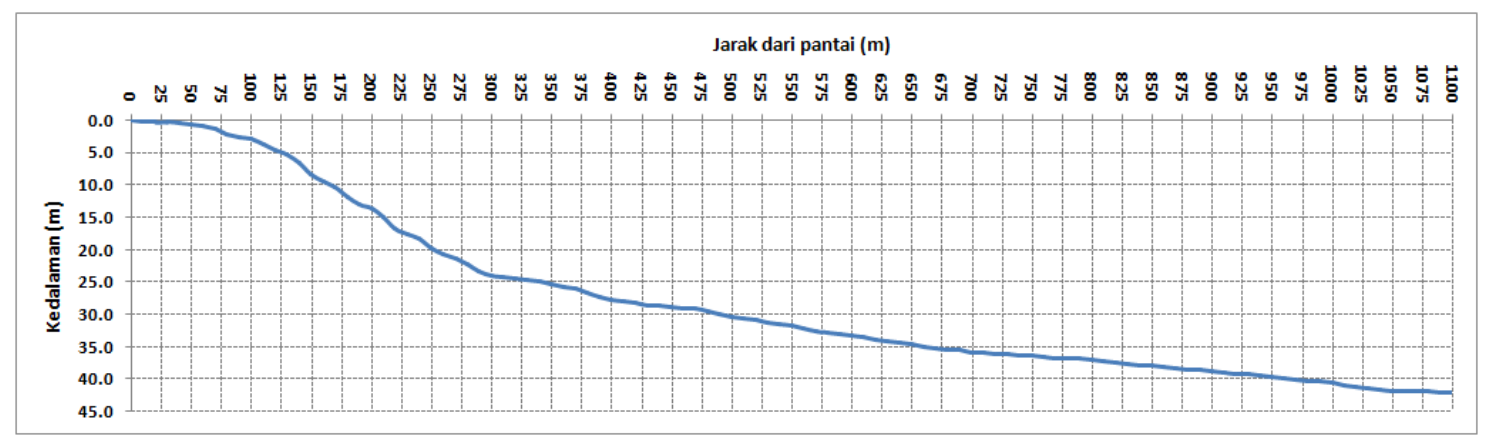

Gambar 6. Irisan profil kedalaman pada garis transek arah utara calon lokasi budidaya

\section{b. Arus Laut}

Hasil observasi arah dan kecepatan arus dengan menggunakan ADCP di titik pengamatan ditampilkan secara lengkap di Tabel L1 pada lembar Lampiran. Sementara itu visualisasinya diperlihatkan pada Gambar 7 s.d. Gambar 11. 


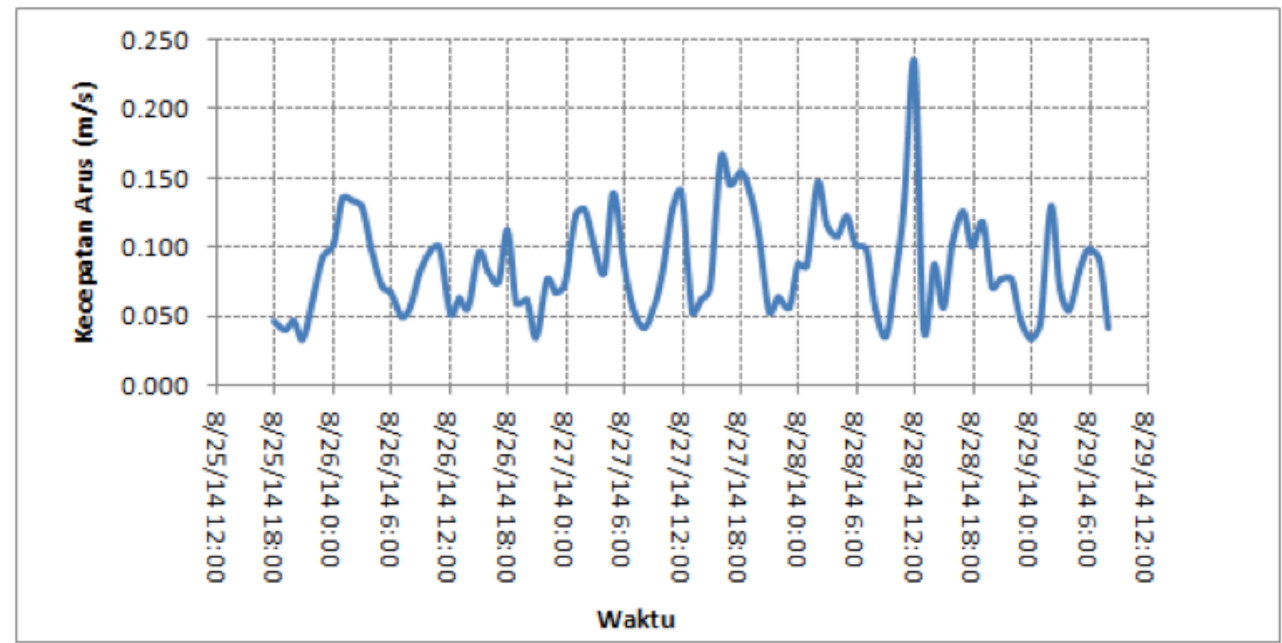

Gambar 7. Grafik kecepatan arus pada kedalaman 0 - 5 meter

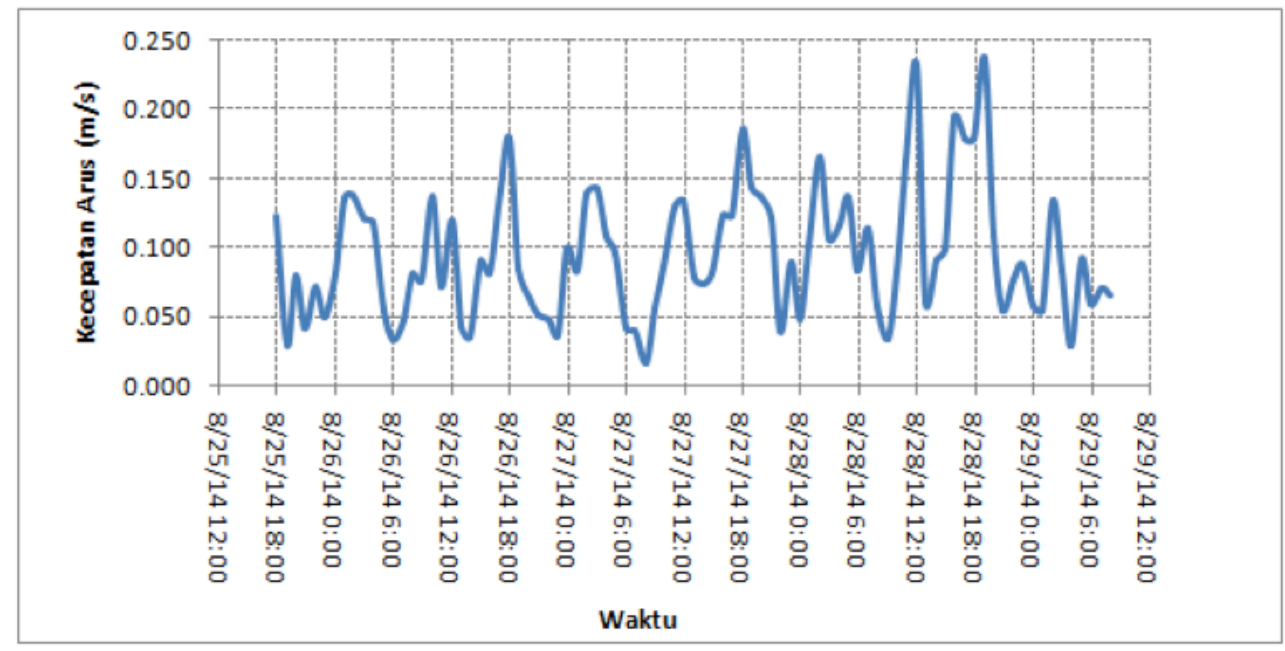

Gambar 8. Grafik kecepatan arus pada kedalaman 6 - 10 meter

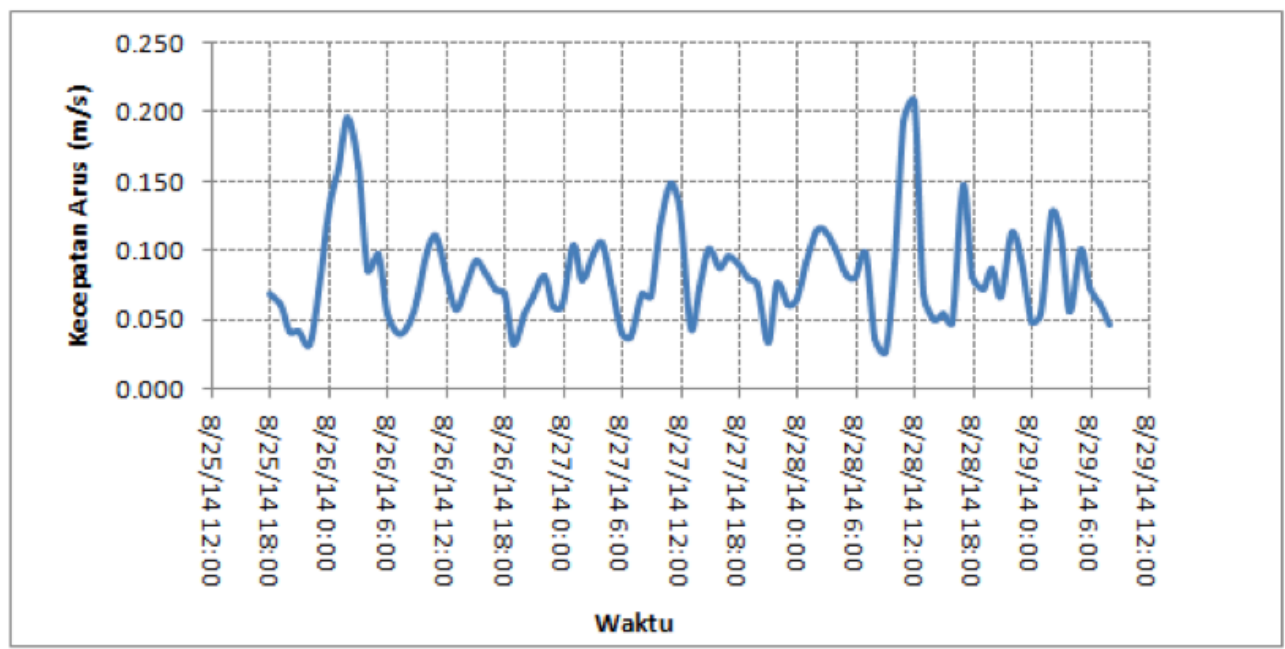

Gambar 9. Grafik kecepatan arus pada kedalaman 11 - 15 meter 


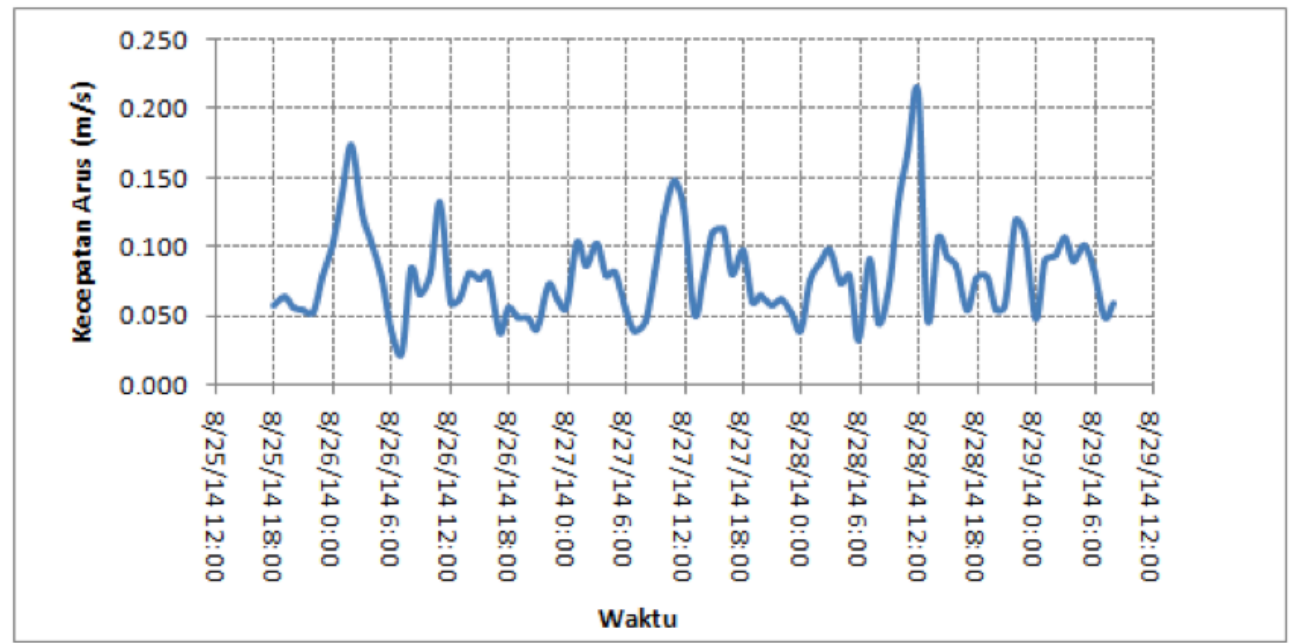

Gambar 10. Grafik kecepatan arus pada kedalaman 16 - 20 meter

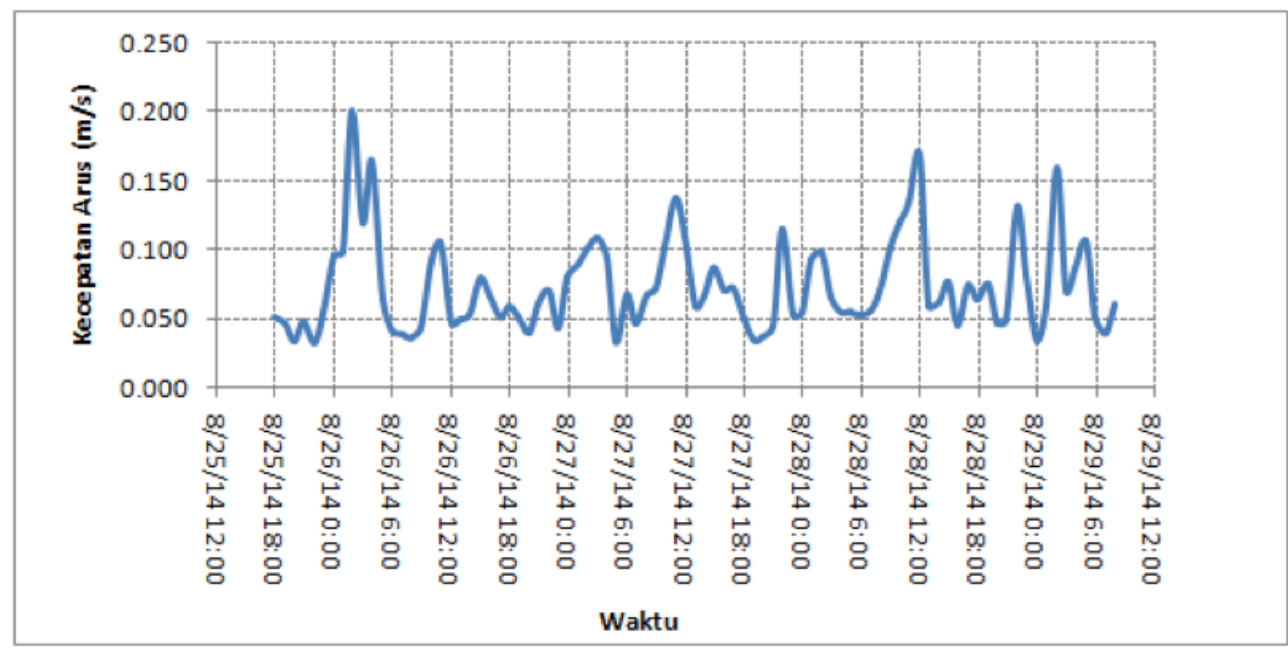

Gambar 11. Grafik kecepatan arus pada kedalaman 21 - 25 meter

Grafik mawar arus (current rose) digunakan untuk menggambarkan distribusi arah dan kecepatan arus dominan pada beberapa lapisan. Prosentase dalam lingkaran garis putusputus menunjukkan banyaknya arus yang menuju ke arah tertentu dalam persen, sedangkan warna menunjukkan kisaran kecepatan arus. Dari Gambar 12 terlihat rata-rata arus di semua kedalaman dominan mengarah ke barat dengan kisaran kecepatan 0,1-0,2 m/det. 


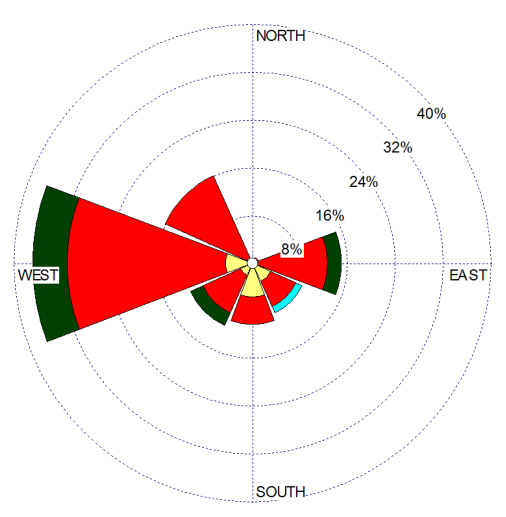

0 - 5 meter

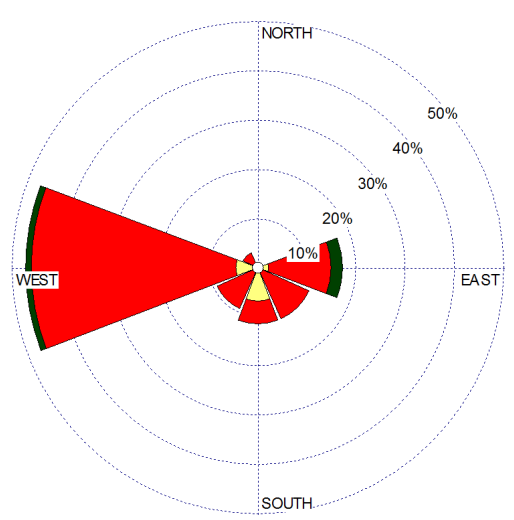

$16-20$ meter

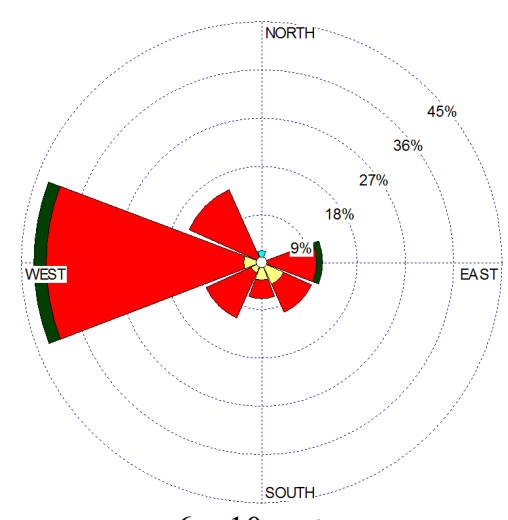

$6-10$ meter

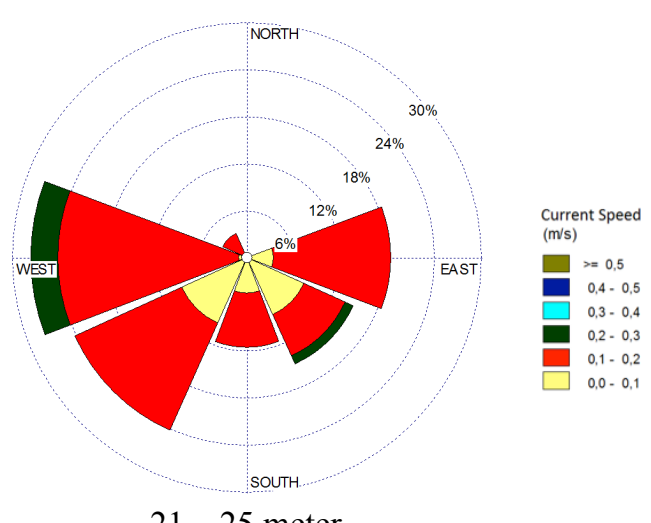

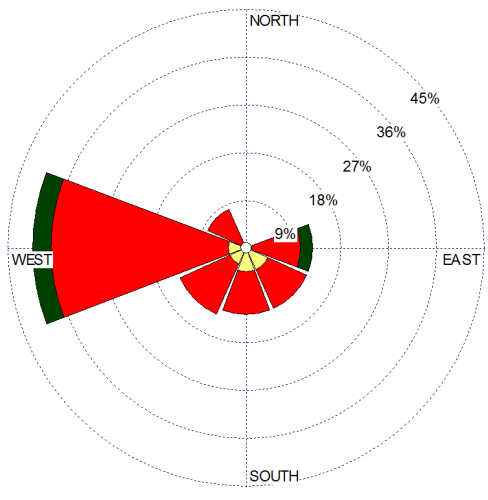

$11-15$ meter

Gambar 12. Mawar arus di perairan Desa Musi, Kecamatan Gerokgak, Kabupaten Buleleng, Bali

\section{c. Pasang Surut}

Hasil observasi pasang surut dengan menggunakan sensor tekanan pada ADCP di titik pengamatan ditampilkan pada Tabel 5. Overlay grafik pasang surut hasil pengukuran terhadap hasil prediksi di daerah kajian diperlihatkan pada Gambar 13. Sementara itu penentuan tipe pasang surut di wilayah kajian diberikan pada Tabel 6. 
Tabel 5. Elevasi pasang surut di pesisir Desa Musi hasil pengukuran

\begin{tabular}{cccccc}
\hline \multicolumn{5}{c}{ Tanggal } \\
\hline Jam & $25 / 8 / 2014$ & $26 / 8 / 2014$ & $27 / 8 / 2014$ & $28 / 8 / 2014$ & $29 / 8 / 2014$ \\
00:00 & - & 0,33 & 0,36 & 0,38 & 0,35 \\
01:00 & - & 0,29 & 0,35 & 0,42 & 0,42 \\
\hline $\mathbf{0 2 : 0 0}$ & - & 0,70 & 0,24 & 0,33 & 0,39 \\
$\mathbf{0 3 : 0 0}$ & - & 0,02 & 0,08 & 0,18 & 0,24 \\
$\mathbf{0 4 : 0 0}$ & - & $-0,12$ & $-0,08$ & $-0,01$ & 0,07 \\
$\mathbf{0 5 : 0 0}$ & - & $-0,18$ & $-0,20$ & $-0,17$ & $-0,12$ \\
$\mathbf{0 6 : 0 0}$ & - & $-0,17$ & $-0,24$ & $-0,25$ & $-0,25$ \\
$\mathbf{0 7 : 0 0}$ & - & $-0,07$ & $-0,18$ & $-0,24$ & $-0,28$ \\
$\mathbf{0 8 : 0 0}$ & - & 0,09 & $-0,04$ & $-0,14$ & $-0,23$ \\
$\mathbf{0 9 : 0 0}$ & - & 0,26 & 0,13 & 0,00 & $-0,13$ \\
$\mathbf{1 0 : 0 0}$ & - & 0,41 & 0,28 & 0,16 & - \\
$\mathbf{1 1 : 0 0}$ & - & 0,51 & 0,41 & 0,30 & - \\
$\mathbf{1 2 : 0 0}$ & - & 0,51 & 0,47 & 0,41 & - \\
$\mathbf{1 3 : 0 0}$ & - & 0,36 & 0,43 & 0,43 & - \\
$\mathbf{1 4 : 0 0}$ & - & 0,13 & 0,24 & 0,31 & - \\
$\mathbf{1 5 : 0 0}$ & - & $-0,14$ & $-0,01$ & 0,10 & - \\
$\mathbf{1 6 : 0 0}$ & - & $-0,38$ & $-0,25$ & $-0,13$ & - \\
$\mathbf{1 7 : 0 0}$ & - & $-0,55$ & $-0,43$ & $-0,32$ & - \\
$\mathbf{1 8 : 0 0}$ & $-0,67$ & $-0,61$ & $-0,52$ & $-0,42$ & - \\
$\mathbf{1 9 : 0 0}$ & $-0,55$ & $-0,56$ & $-0,50$ & $-0,43$ & - \\
$\mathbf{2 0 : 0 0}$ & $-0,36$ & $-0,40$ & $-0,38$ & $-0,35$ & - \\
$\mathbf{2 1 : 0 0}$ & $-0,12$ & $-0,19$ & $-0,18$ & $-0,20$ & - \\
$\mathbf{2 2 : 0 0}$ & 0,09 & 0,04 & 0,04 & $-0,02$ & - \\
$\mathbf{2 3 : 0 0}$ & 0,27 & 0,24 & 0,24 & 0,18 & - \\
\hline & & & & & \\
\hline
\end{tabular}

Tabel 6. Tipe pasang surut berdasarkan bilangan Formzahl (F)

\begin{tabular}{crccc}
\hline & \multicolumn{4}{c}{ Komponen Pasut } \\
\cline { 2 - 5 } & $\mathrm{M} 2$ & $\mathrm{~S} 2$ & $\mathrm{~K} 1$ & $\mathrm{O} 1$ \\
\hline Amplitudo $(\mathrm{m})$ & 0,3364 & 0,1195 & 0,4945 & 0,2435 \\
$F=\frac{A_{K 1}+A_{O 1}}{A_{M 2}+A_{S 2}}$ & 1,619 & & & \\
\end{tabular}

Tipe Pasut: campuran cenderung ke harian ganda

Perhitungan tipe pasang surut di pesisir Desa Musi dilakukan dengan mengacu pada data pengamatan pasang surut di perairan Gondol, hal ini didasarkan pada perairan yang berada di satu wilayah dan ketersediaan data yang lebih panjang. Analisa data pasang surut memperlihatkan pasang surut di daerah tersebut termasuk pada tipe campuran condong ke harian ganda yaitu dalam satu hari terjadi dua kali air pasang dan dua kali air surut, tetapi dengan tinggi dan periode berbeda. Selain tipe pasang surut, berdasar data rekaman fluktuasi muka air laut juga dapat dihitung perkiraan elevasi acuan pasang surut 
untuk daerah kajian. Tabel 7 memperlihatkan perkiraan elevasi acuan yang diperoleh dari perhitungan berdasar data rekaman pasang surut di perairan Gondol.

Tabel 7. Elevasi acuan untuk perairan pesisir Gondol dan sekitarnya

\begin{tabular}{clc}
\hline No. & \multicolumn{1}{c}{ Elevasi Acuan } & $\begin{array}{c}\text { Nilai dari MSL } \\
(\mathbf{m})\end{array}$ \\
\hline 1. & HHWL (Highest High Water Level) & 1,194 \\
2. & MHWS (Mean High Water Spring) & 0,455 \\
3. & MHWL (Mean High Water Level) & 0,216 \\
4. & MSL (Mean Sea Level) & 0,000 \\
5. & MLWL (Mean Low Water Level) & $-0,217$ \\
6. & MLWS (Mean Low Water Spring) & $-0,456$ \\
7. & LLWL (Lowest Low Water Level) & $-1,194$ \\
\hline
\end{tabular}

\section{Keterangan:}

HHWL = Elevasi muka air tertinggi

MHWS = Rata-rata elevasi puncak tertinggi pasut saat purnama

MHWL = Rata-rata elevasi semua puncak pasut

MSL = Rata-rata elevasi semua muka air

MLWL = Rata-rata elevasi semua lembah pasut

MLWS = Rata-rata elevasi lembah terendah pasut saat purnama

LLWL = Elevasi muka air terendah

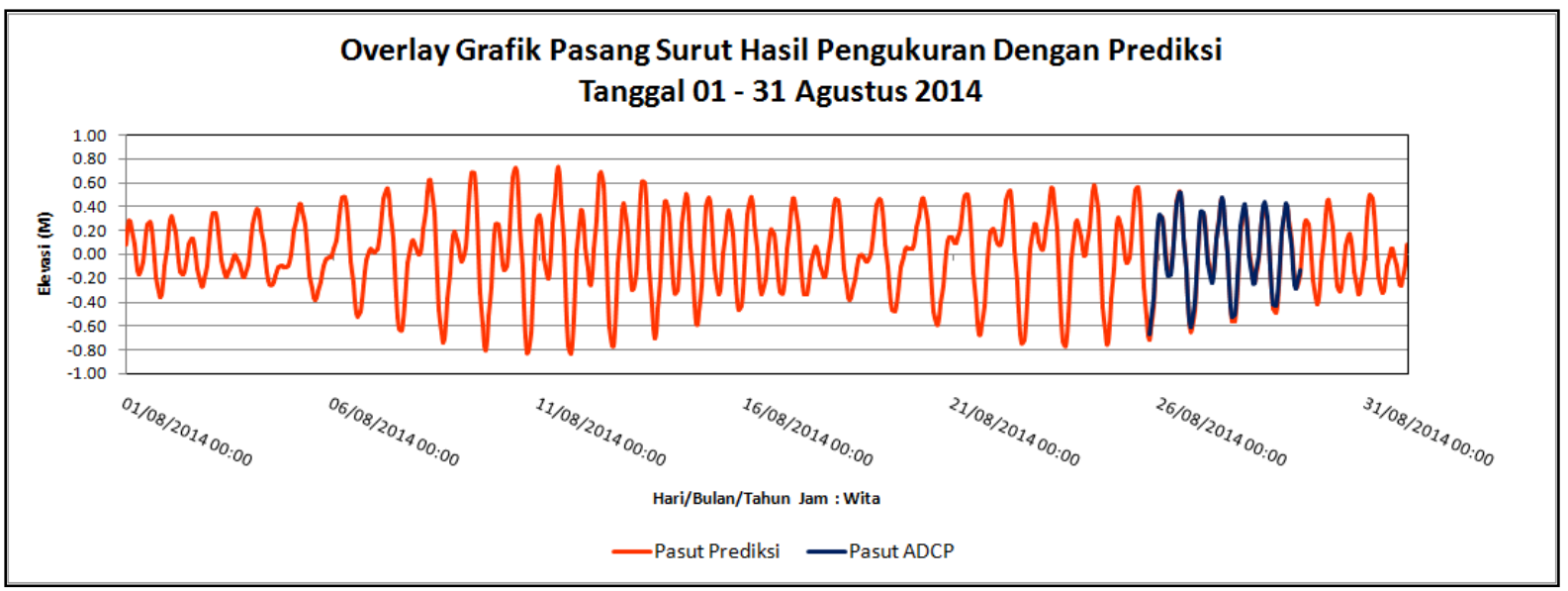

Gambar 13. Pasang surut di perairan Desa Musi, Kabupaten Buleleng bulan Agustus 2014

\section{HASIL SURVEY KUALITAS PERAIRAN}

Secara umum, kondisi perairan yang baik dapat diamati dari hasil pengukuran kualitas perairan yang tidak melebihi baku mutu air laut untuk biota laut. Salah satu yang dapat dijadikan acuan sebagai standar baku mutu air laut untuk biota laut adalah Kepmen LH No.

51 Tahun 2004 (Tabel 8). 
Tabel 8. Baku mutu air laut untuk biota laut berdasarkan Kepmen LH No. 51 Tahun 2004

\begin{tabular}{|c|c|c|c|c|}
\hline & Parameter & Satuan & Baku Mutu & Catatan \\
\hline & & & & \\
\hline 1 & Suhu & ${ }^{\circ} \mathrm{C}$ & Alami & Diperbolehkan terjadi perubahan \\
\hline & & & Karang: $28-30$ & sampai dengan $<2^{\circ} \mathrm{C}$ dari suhu alami \\
\hline & & & Mangrove: $28-32$ & \\
\hline & & & Lamun: $28-30$ & \\
\hline 2 & Kecerahan & $\mathrm{m}$ & Alami & Diperbolehkan terjadi perubahan \\
\hline & & & Karang: $28-30$ & sampai dengan $<10 \%$ kedalaman \\
\hline & & & Mangrove: $28-32$ & \\
\hline & & & Lamun: $28-30$ & \\
\hline 3 & Kekeruhan & NTU & $<5$ & $\begin{array}{l}\text { Diperbolehkan terjadi perubahan } \\
\text { sampai dengan }<10 \% \text { kedalaman } \\
\text { euphotic }\end{array}$ \\
\hline 4 & Salinitas & $\%$ & Alami & Diperbolehkan terjadi perubahan \\
\hline & & & Karang: $33-34$ & sampai dengan $<5 \%$ salinitas rata- \\
\hline & & & Mangrove: s/d 34 & rata musiman \\
\hline & & & Lamun: 33-34 & \\
\hline 5 & Padatan Tersuspensi & $\mathrm{mg} / \mathrm{L}$ & Karang: 20 & Diperbolehkan terjadi perubahan \\
\hline & Total & & Mangrove: 80 & sampai dengan $<10 \%$ konsentrasi \\
\hline & & & Lamun: 20 & rata-rata musiman \\
\hline & & & & \\
\hline 6 & $\mathrm{pH}$ & - & $7-8,5$ & $\begin{array}{l}\text { Diperbolehkan terjadi perubahan } \\
\text { sampai dengan }<0,2 \text { satuan } \mathrm{pH}\end{array}$ \\
\hline 7 & $\begin{array}{l}\text { Oksigen terlarut } \\
\text { (DO) }\end{array}$ & $\mathrm{mg} / \mathrm{L}$ & $>5$ & - \\
\hline 8 & Ammonia $\left(\mathrm{NH}_{3}-\mathrm{N}\right)$ & $\mathrm{mg} / \mathrm{L}$ & 0,3 & - \\
\hline 9 & Fosfat $\left(\mathrm{PO}_{4}-\mathrm{P}\right)$ & $\mathrm{mg} / \mathrm{L}$ & 0,015 & - \\
\hline
\end{tabular}

Keterangan: alami adalah kondisi normal suatu lingkungan, bervariasi setiap saat (siang, malam dan musim).

\section{a. Suhu Permukaan Laut}

Secara umum suhu permukaan laut di perairan Desa Musi, Kecamatan Gerokgak, Kabupaten Buleleng, Bali berada pada kisaran $27,80^{\circ} \mathrm{C}$ hingga $29,70^{\circ} \mathrm{C}$, dengan rerata $28,49 \pm 0,50^{\circ} \mathrm{C}$. Pada Gambar 14, jika melihat pada kondisi pasang surutnya (panel paling atas pada Gambar 14), suhu permukaan laut pada setiap stasiun pengamatan menjadi lebih hangat ketika air menuju surut. Peningkatan yang relatif cukup signifikan ditemukan pada Stasiun 1 dan 2 yang lokasinya lebih dekat ke pantai daripada Stasiun 3 dan 4 . Hal ini mengindikasikan bahwa pasang surut berpengaruh cukup signifikan terhadap variasi pasang surut di stasiun-stasiun tersebut. Mengacu pada Kepmen LH No. 51 Tahun 2004, dimana baku mutu suhu air laut untuk perairan karang adalah berkisar antara $28^{\circ} \mathrm{C}$ dan $32^{\circ} \mathrm{C}$ dengan perubahan yang diperbolehkan hingga $<2^{\circ} \mathrm{C}$ dari suhu air laut alami, maka secara umum suhu di perairan Desa Musi masih berada dalam kisaran normal untuk kehidupan biota laut. 

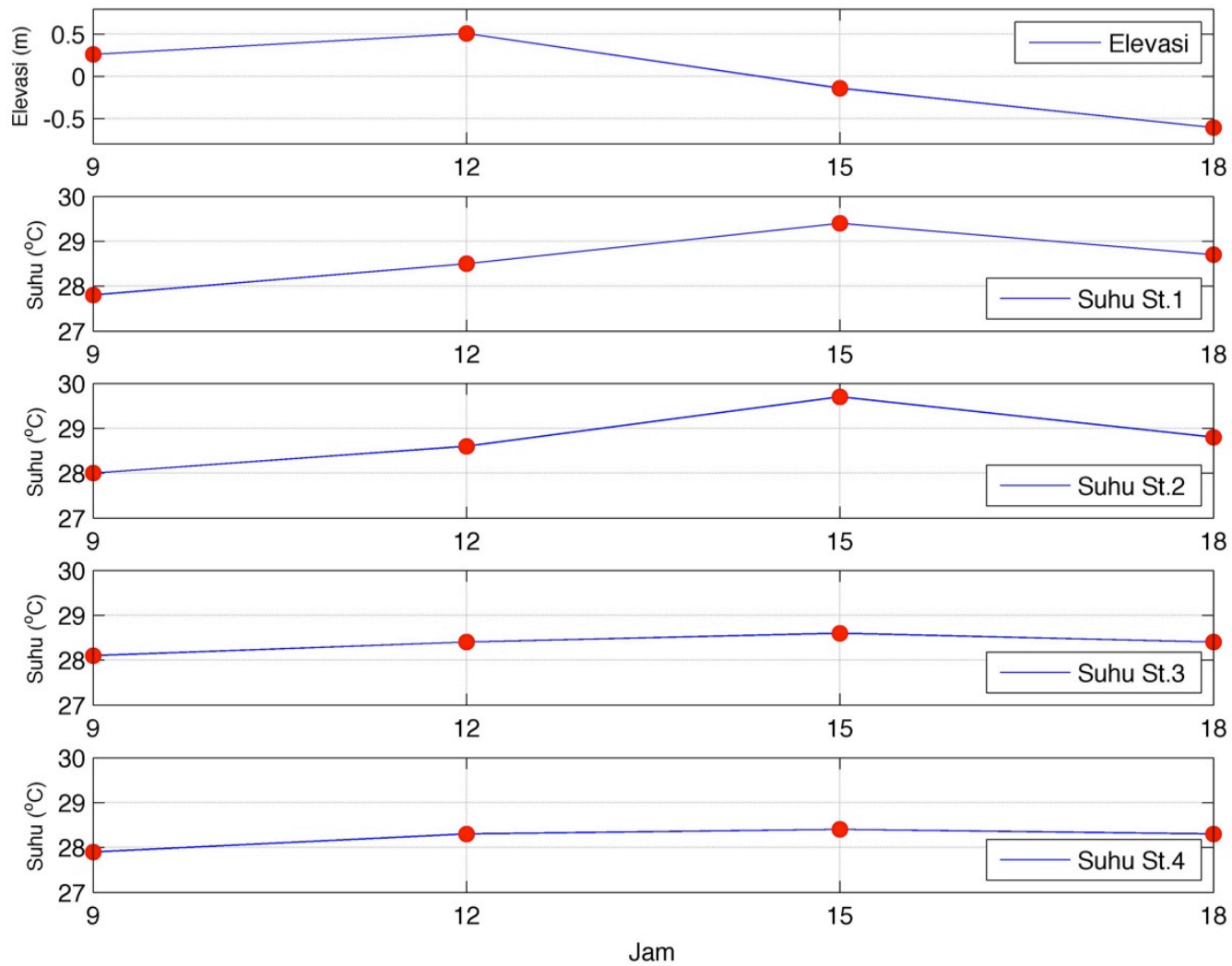

Gambar 14. Hasil pengukuran suhu permukaan laut di Stasiun 1 - 4 Perairan Desa Musi, Kabupaten Buleleng, Bali

\section{b. Oksigen Terlarut (Dissolved Oxygen)}

Berdasarkan hasil pengukuran, nilai oksigen terlarut (DO) di perairan Desa Musi berkisar antara 5,35 ml/L hingga 7,54 ml/L dengan rerata 6,52 $\pm 0,60 \mathrm{ml} / \mathrm{L}$ (Gambar 15). Secara umum, nilai DO di Stasiun 1, 3, dan 4 mengikuti pola pasang surutnya, sementara itu di Stasiun 2 sedikit memiliki pola yang berbeda. Dari hasil pengukuran, nilai DO tertinggi didapatkan di Stasiun 3 (7,54 ml/L; 12.00 WITA), sementara Stasiun 2 (5,35 ml/L;09.00 WITA) memiliki nilai DO terendah. Berdasarkan Kepmen LH No. 51 Tahun 2004, baku mutu DO untuk biota laut adalah $>5 \mathrm{ml} / \mathrm{L}$. Nilai DO yang melebihi $5 \mathrm{ml} / \mathrm{L}$ di seluruh stasiun pengamatan pada saat pengambilan data dapat dikaitkan dengan suhu permukaan laut di perairan Desa Musi yang relatif rendah, sehingga meningkatkan kelarutan gas oksigen dalam air laut. Menurut Makmur et al. (2010), selain suhu, tingginya nilai DO dapat dipengaruhi pula oleh proses fisis yang mempengaruhi kecepatan oksigen terlarut dan terdistribusi di dalam kolom air laut serta proses biologis yang mengontrol tingkat konsumsi dan pembebasan oksigen. 

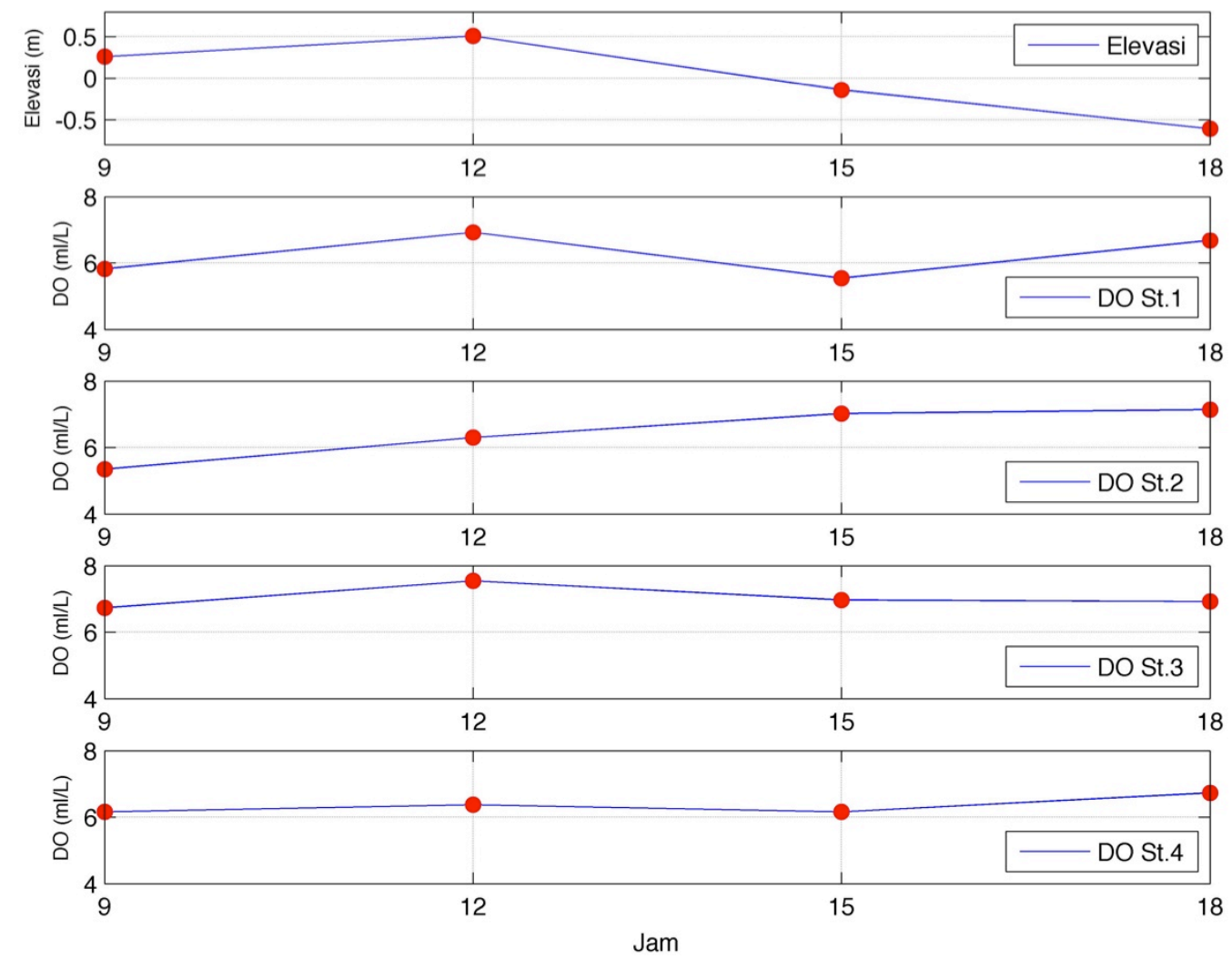

Gambar 15. Hasil pengukuran oksigen terlarut di Stasiun $1-4$ Perairan Desa Musi, Kabupaten Buleleng, Bali

\section{c. Salinitas}

Salinitas merupakan komposisi kimia perairan yang menyatakan kadar garam terlarut dalam perairan. Berdasarkan Gambar 16, nilai salinitas di stasiun pengamatan berkisar antara 33 sampai 33,90, dimana salinitas tertinggi terdapat di Stasiun 4 dengan waktu pengambilan data pukul 12.00 dan salinitas terendah terdapat di Stasiun 1 dengan waktu pengambilan data pukul 09.00 dan 18.00 yang masing-masing nilai salinitas nya adalah 33,90 dan 33,00. Jika dilihat nilai salinitas yang ditampilkan pada Gambar 15, waktu pengambilan data pada siang hari menunjukkan nilai salinitas tertinggi. Hal ini dikarenakan pada siang hari terjadi penguapan yang menyebabkan salinitas perairan menjadi tinggi. Jika dikaitkan dengan kondisi pasang surut selama pengambilan data, dapat dilihat bahwa pada Stasiun 3 variasi salinitasnya relatif kecil jika dibandingkan dengan Stasiun 1,2, dan 4. Mengacu pada Kepmen LH No. 51 Tahun 2004, dimana baku mutu salinitas air laut untuk perairan karang adalah berkisar antara 33 dan 34 dengan perubahan yang diperbolehkan hingga $<5$ salinitas rata-rata musiman, maka secara umum salinitas di perairan Desa Musi masih berada dalam kisaran normal untuk kehidupan biota laut. 

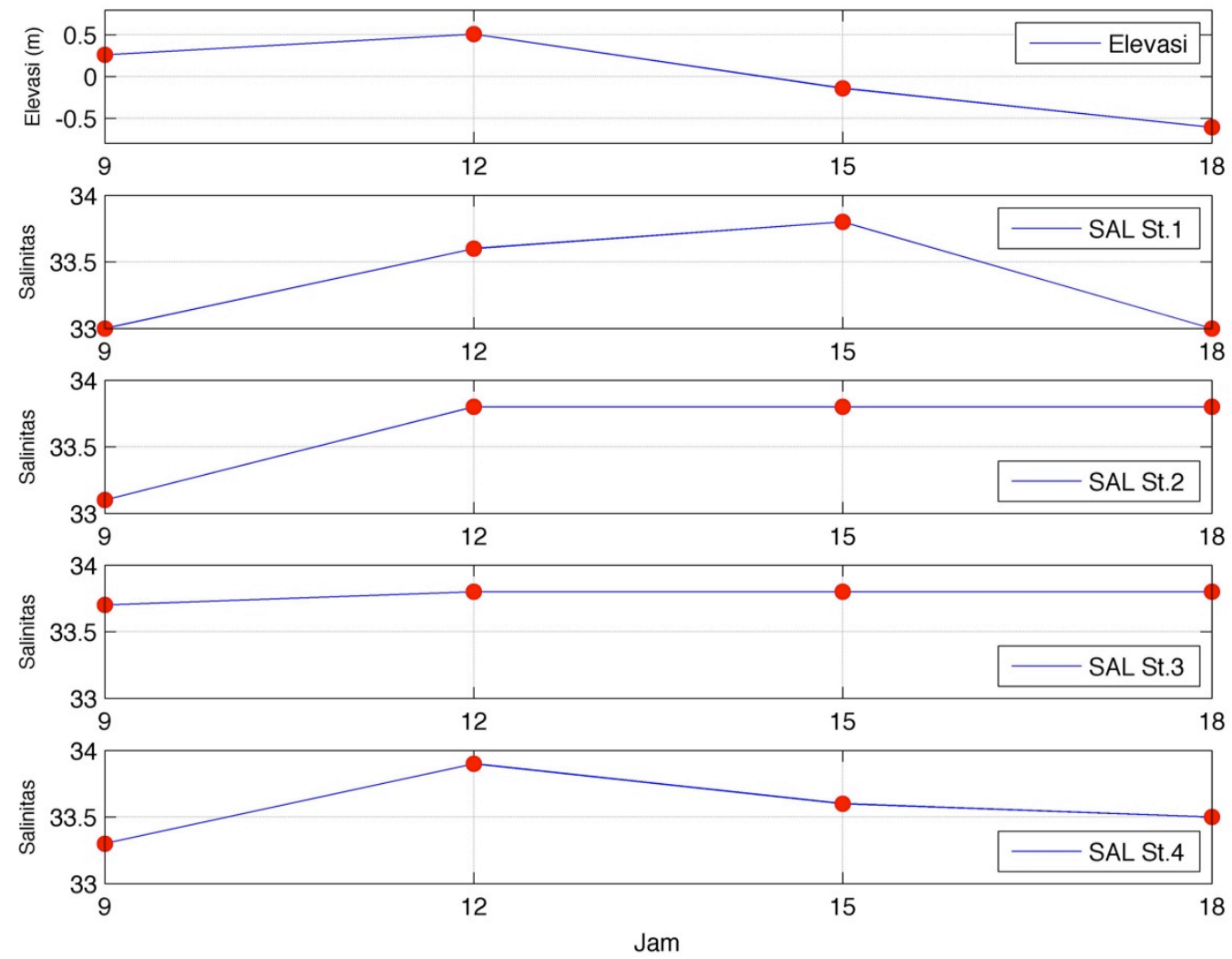

Gambar 16. Hasil pengukuran salinitas di Stasiun 1 - 4 Perairan Desa Musi, Kabupaten Buleleng, Bali

\section{d. $\mathrm{pH}$}

Derajat keasaman $(\mathrm{pH})$ digunakan untuk menyatakan tingkat keasaman atau kebasaan yang dimiliki oleh suatu larutan, dalam hal ini larutan yang dimaksud adalah air laut. Berdasarkan Gambar 17, pH di stasiun pengamatan berkisar antara 8,150 sampai 8,504. Nilai $\mathrm{pH}$ tertinggi terdapat di Stasiun 2 yaitu 8,504 dengan waktu pengambilan data pukul 18.00 WITA, sedangkan nilai $\mathrm{pH}$ terendah terdapat di Stasiun 4 yaitu 8,150 dengan waktu pengambilan data pukul 12.00 WITA. Secara umum, variasi pH di Stasiun 1, 2, 3, dan 4 hampir sama, yaitu lebih tinggi pada saat menuju surut, hanya saja variasi di Stasiun 1 dan 3 relatif lebih kecil.

Mengacu pada Kepmen LH No. 51 Tahun 2004, dimana baku mutu pH air laut untuk perairan karang adalah berkisar antara 7 dan 8,5 dengan perubahan yang diperbolehkan hingga $<0,2$ satuan $\mathrm{pH}$, maka secara umum $\mathrm{pH}$ di perairan Desa Musi masih berada dalam kisaran normal untuk kehidupan biota laut. 

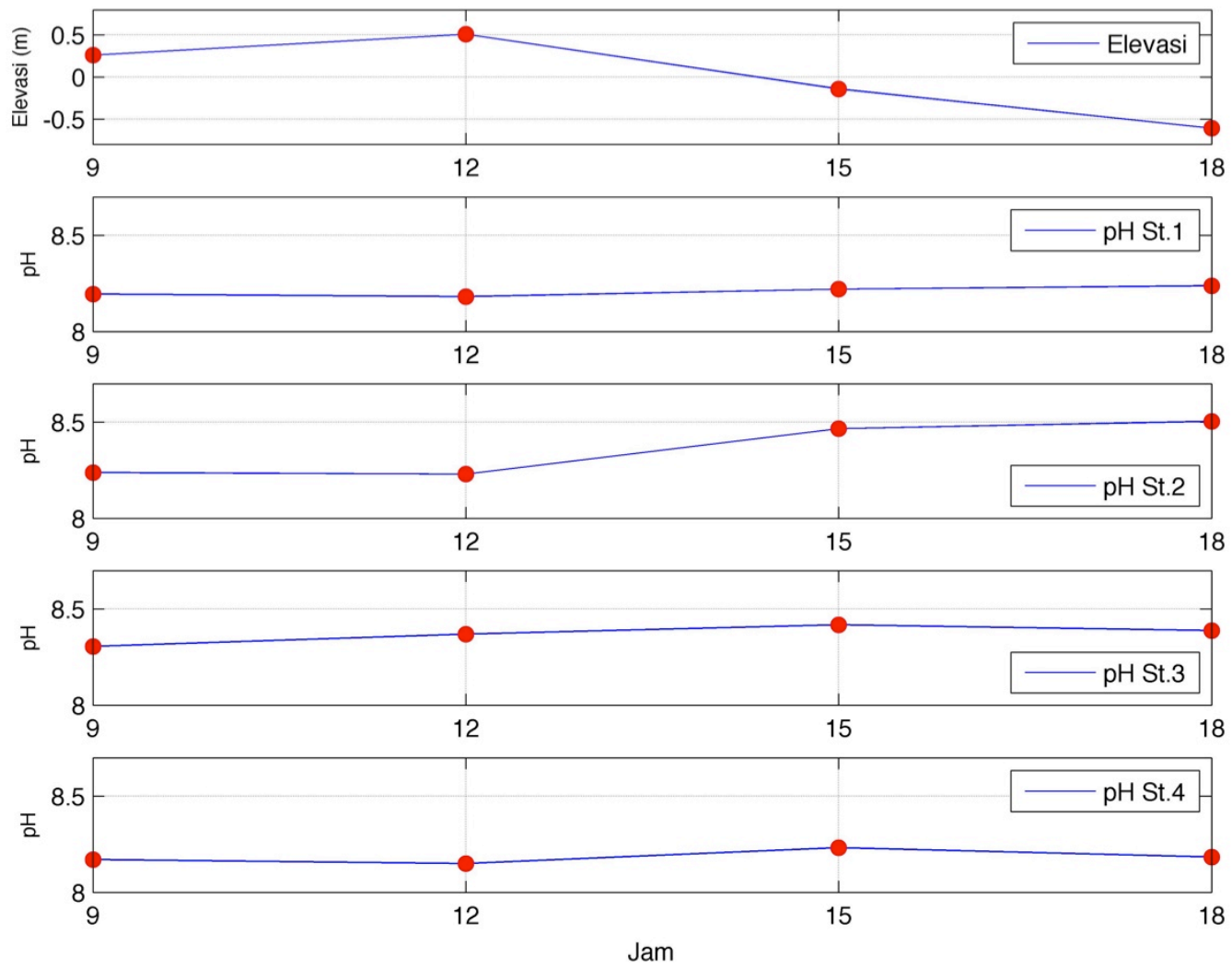

Gambar 17. Hasil pengukuran pH di Stasiun 1 - 4 Perairan Desa Musi, Kabupaten Buleleng, Bali

\section{e. Kecerahan (Visibility)}

Menurut Effendi (2013), kecerahan merupakan ukuran transparansi perairan yang ditentukan secara visual dengan menggunakan Secchi disk. Nilai kecerahan yang dinyatakan dalam satuan meter ini sangat dipengaruhi oleh keadaan cuaca, waktu pengukuran, kekeruhan padatan tersuspensi dan ketelitian saat pengambilan data. Oleh sebab itu, pengukuran kecerahan sebaiknya dilakukan saat cuaca cerah. Secara umum, kecerahan perairan Desa Musi di setiap stasiun pengamatan menunjukkan hasil yang bervariasi, yang berkisar antara $5-20 \mathrm{~m}$ dengan rerata $9,7 \pm 3,8 \mathrm{~m}$. Jika melihat dari kedalaman stasiun pengamatan (lihat Tabel 4), maka Stasiun 2, 3, dan 4 tergolong memiliki kecerahan yang relatif cukup rendah. Berdasarkan Gambar 18, kecerahan maksimum di Stasiun 2 yang memiliki kedalaman 28,8 m adalah $20 \mathrm{~m}$ pada pukul 09.00 WITA, namun di waktu-waktu lainnya kecerahannya hanya $10 \mathrm{~m}$, bahkan pada pukul 12.00 dan 15.00 berada di bawah $10 \mathrm{~m}$. Demikian juga dengan Stasiun 3 yang memiliki kedalaman 32,5 m, kecerahan maksimumnya adalah adalah $16 \mathrm{~m}$. 
Jika mengacu pada nilai Kepmen LH No. 51 Tahun 2004, kisaran kecerahan dari perairan karang adalah antara 28 dan $30 \mathrm{~m}$, dan diperbolehkan terjadi perubahan sampai dengan $<10 \%$ kedalaman euphotic. namun dapat bervariasi secara alamiah akibat perubahan waktu dan musim. Nilai kecerahan yang rendah dari perairan Desa Musi saat dilakukannya pengambilan data kemungkinan disebabkan oleh stasiun-stasiun pengamatan yang memiliki kedalaman rendah.
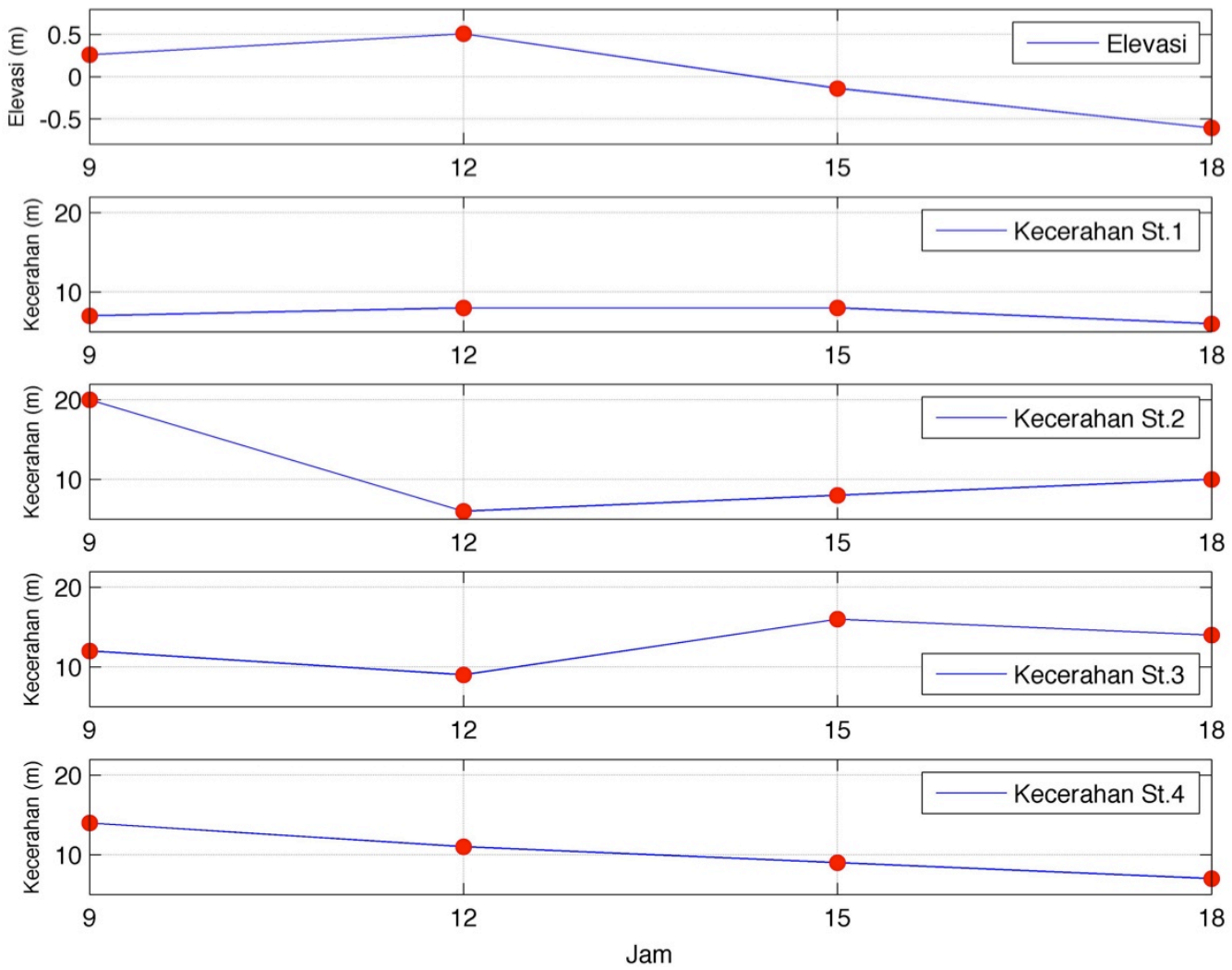

Gambar 18. Hasil Pengukuran Kecerahan di Stasiun 1 - 4 Perairan Desa Musi, Kabupaten Buleleng, Bali

\section{f. Kekeruhan (Turbiditas)}

Turbiditas merupakan suatu ukuran yang menyatakan sampai seberapa jauh cahaya mampu menembus air. Berdasarkan Gambar 19 dapat diketahui bahwa nilai turbiditas tertinggi terdapat pada Stasiun 2 dengan waktu pengambilan sampel air pukul 09.00 WITA yaitu 1,8 NTU. Pada beberapa titik dan pengambilan sampel air nilai turbiditas bernilai nol, yaitu di Stasiun 1 pukul 15.00 WITA dan Stasiun 2 pukul 18.00 WITA. Secara umum, nilai turbiditas dari perairan Desa Musi masih di bawah nilai ambang batas Kepmen LH No. 51 Tahun 2004, yaitu kurang dari 5 NTU. 

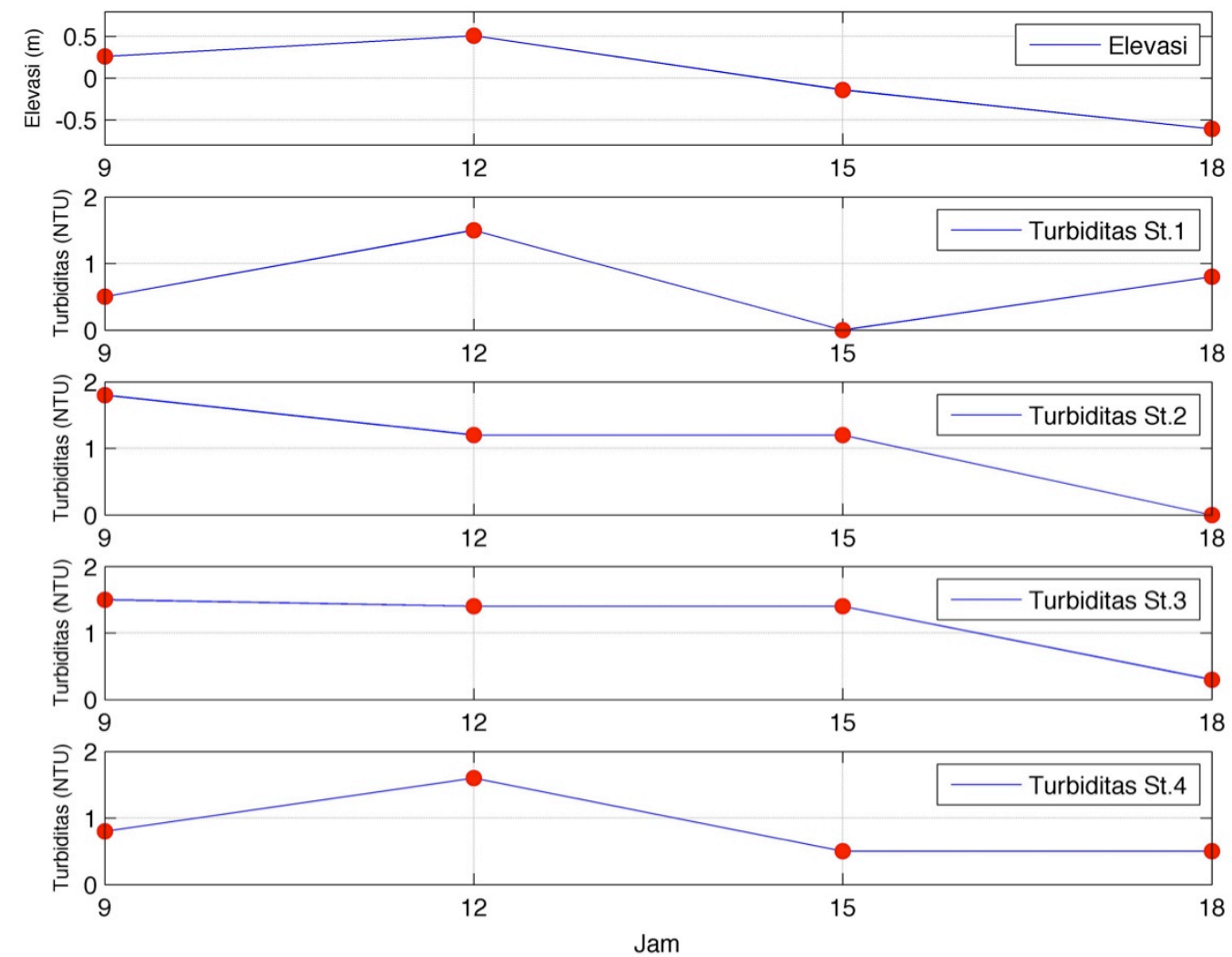

Gambar 19. Hasil pengukuran turbiditas di Stasiun 1 - 4 Perairan Desa Musi, Kabupaten Buleleng, Bali

\section{g. Benthic Macroinvertebrate dan Benthic Soil Type}

Tabel 9 merupakan tabel kepadatan bentos di stasiun pengambilan data. Bentos adalah organisme yang hidup di dasar perairan (substrat) baik yang sesil, merayap maupun menggali lubang. Terdapat 3 kelas bentos yang ditemukan di stasiun pengambilan data, yaitu kelas polychaeta, crustacean dan echinodermata. Polychaeta adalah kelas cacing annelida yang umumnya hidup di laut, ditemukan di Stasiun 1 dan Stasiun 3. Adapun spesies polychaeta yang ditemukan di Stasiun 1 adalah Onuphis sp., Pholoe sp., dan Goniada sp., sedangkan di Stasiun 3 adalah Lumbrineris sp. Bentos yang ditemukan di Stasiun 2 dalah Callianassa sp. dari kelas crustacea dengan kepadatan $50 \mathrm{ind} / \mathrm{m}^{2}$. Crustacea adalah organisme dengan tubuh bersegmentasi (beruas-ruas). Stasiun 3 merupakan stasiun dengan indeks keragaman bentos yang paling tinggi yaitu 2,26. Hal ini dikarenakan di Stasiun 3 ditemukan 5 taksa dengan 3 kelas berbeda. Kepadatan bentos di Stasiun 3 adalah $101 \mathrm{ind} / \mathrm{m}^{2}$. Adapun spesies bentos yang ditemukan di Stasiun 3 adalah Goniada sp., Lumbrineris sp., Callianassa sp., Oratosquilla sp., dan F. Peneidae. Di Stasiun 4 ditemukan bentos dari kelas echinodermata yaitu Amphiura sp. Echinodermata adalah invertebrata dengan kulit berduri. 
Tabel 9. Kepadatan bentos di sedimen perairan Desa Musi Kabupaten Buleleng, Bali

\begin{tabular}{|c|c|c|c|c|c|}
\hline Kelas & Organisme & Sta 1 & Sta 2 & Sta 3 & Sta 4 \\
\hline \multirow{4}{*}{ Polychaeta } & Onuphis sp. & 17 & 0 & 0 & 0 \\
\hline & Pholoe sp. & 17 & 0 & 0 & 0 \\
\hline & Goniada sp. & 17 & 0 & 17 & 0 \\
\hline & Lumbrineris sp. & 0 & 0 & 17 & 0 \\
\hline \multirow{3}{*}{ Crustacea } & Callianassa sp. & 0 & 50 & 33 & 50 \\
\hline & Oratosquilla sp. & 0 & 0 & 17 & 0 \\
\hline & F. Peneidae (sp1) & 0 & 0 & 17 & 0 \\
\hline Echinodermata & Amphiura sp. & 0 & 0 & 0 & 17 \\
\hline Jumlah Taksa & & 3 & 1 & 5 & 2 \\
\hline Kepadatan (ind $/ \mathrm{m}^{2}$ ) & & 51 & 50 & 101 & 67 \\
\hline Indeks Keragaman & & 1,58 & 0,00 & 2,26 & 0,82 \\
\hline Indeks Keseragaman & & 1,00 & - & 0,97 & 0,82 \\
\hline Indeks Dominansi & & 0,33 & 1,00 & 0,22 & 0,62 \\
\hline
\end{tabular}

\section{h. Sedimen Dasar}

Diameter sedimen hasil pengujian laboratorium untuk sedimen dasar perairan setiap stasiun ditampilkan pada Tabel 10. Sedimen dasar perairan terbagi menjadi 5 jenis fraksi yaitu pasir sangat kasar, pasir kasar, pasir sedang, pasir halus dan pasir sangat halus. Masing-masing dari fraksi tersebut memiliki diameter sedimen yang berbeda. Fraksi sedimen di Stasiun 1, Stasiun 2 dan Stasiun 3 terdiri dari pasir sedang, pasir halus dan pasir sangat halus dimana di Stasiun 1 dan 2 prosentase komposisi ukuran butir sedimen adalah pasir sangat halus yang nilainya masing-masing $49,12 \%$ dan $46,51 \%$. Sementara itu di Stasiun 3 prosentase komposisi ukuran butir sedimen tertinggi adalah pasir halus yaitu 39,96\%. Di Stasiun 4 fraksi sedimennya terdiri dari pasir sangat kasar $(0,89 \%)$, pasir halus $(82,89 \%)$ dan pasir sangat halus $(16,22 \%)$. Berdasarkan presentase komposisi butir sedimen di stasiun pengamatan, dapat diketahui bahwa sedimen dasar perairan Desa Musi terdiri dari pasir halus dan pasir sangat halus. Perbedaan komposisi butir sedimen di perairan Desa Musi mencirikan proses pengendapan atau pembentukan sedimen yang disebabkan perbedaan kecepatan arus. 
Tabel 10. Persentase komposisi ukuran butiran sedimen pada Stasiun $1-4$

\begin{tabular}{cccccccc}
\hline No & Parameter & $\begin{array}{c}\text { Diameter } \\
(\mathbf{m m})\end{array}$ & Nama Fraksi & $\begin{array}{c}\text { Sta 1 } \\
(\mathbf{\%})\end{array}$ & $\begin{array}{c}\text { Sta 2 } \\
\mathbf{( \% )}\end{array}$ & $\begin{array}{c}\text { Sta 3 } \\
(\mathbf{\%})\end{array}$ & $\begin{array}{c}\text { Sta 4 } \\
(\mathbf{\%})\end{array}$ \\
\hline 1 & F1 & $2-1$ & Pasir sangat kasar & 0,00 & 0,00 & 0,00 & 0,89 \\
\hline 2 & F2 & $1-0,5$ & Pasir kasar & 0,00 & 0,00 & 0,00 & 0,00 \\
\hline 3 & F3 & $0,5-0,2$ & Pasir sedang & 8,82 & 16,35 & 27,04 & 0,00 \\
\hline 4 & F4 & $0,2-0,1$ & Pasir halus & 42,06 & 37,14 & 39,96 & 82,89 \\
\hline 5 & F5 & $0,1-0,05$ & Pasir sangat halus & 49,12 & 46,51 & 33,00 & 16,22 \\
\hline
\end{tabular}

\section{i. Konsentrasi Klorofil-a}

Hasil pengukuran konsentrasi klorofil-a di 4 stasiun pengamatan diberikan pada Gambar 20. Secara umum konsentrasi antar stasiun relatif bervariasi, dimana konsentrasi terbesar ditemukan pada Stasiun 1 yang jaraknya memang paling dekat dari pantai, sementara konsentrasi di 3 stasiun lainnya relatif berada pada kisaran yang hampir sama. Konsentrasi klorofil-a berkisar antara $0,03 \mathrm{mg} / \mathrm{m}^{3}$ hingga $0,20 \mathrm{mg} / \mathrm{m}^{3}$ dengan rerata $0,09 \pm 0,05 \mathrm{mg} / \mathrm{m}^{3}$. Konsentrasi klorofil-a tertinggi ditemukan di Stasiun $1\left(0,20 \mathrm{mg} / \mathrm{m}^{3} ; 09.00\right.$ WITA), sementara konsentrasi klorofil-a terendah didapatkan di Stasiun 2 dan $3\left(0,03 \mathrm{mg} / \mathrm{m}^{3}\right.$; 18.00 WITA). Secara umum konsentrasi klorofil-a di keempat stasiun tersebut bervariasi terhadap siklus pasang surutnya. Di Stasiun 1 konsentrasi klorofil-a maksimum ditemukan pada saat menuju pasang, sementara pada saat pasang maksimum hingga surut minimu konsentrasinya relatif sama. Sedangkan di Stasiun 2 dan 3, konsentrasi klorofil-a pada saat surut minimum lebih kecil daripada pada saat pasang maksimum, dan di Stasiun 4, pada saat surut minimum konsentrasi klorofil-a nya justru lebih besar daripada saat pasang maksimum.

Konsentrasi klorofil-a yang sangat dipengaruhi oleh kelimpahan fitoplankton dapat dijadikan sebagai indikator untuk menentukan kesuburan suatu perairan. Berdasarkan pada data konsentrasi klorofil-a tersebut didapatkan bahwa Stasiun 1 pada saat pengambilan data lebih subur dibandingkan dengan stasiun pengamatan lainnya. Nilai klorofil-a yang kurang dari $1 \mathrm{mg} / \mathrm{m}^{3}$ menandakan bahwa perairan tersebut tidak berpotensi mengalami eutrofikasi (Setiawan, 2013). 

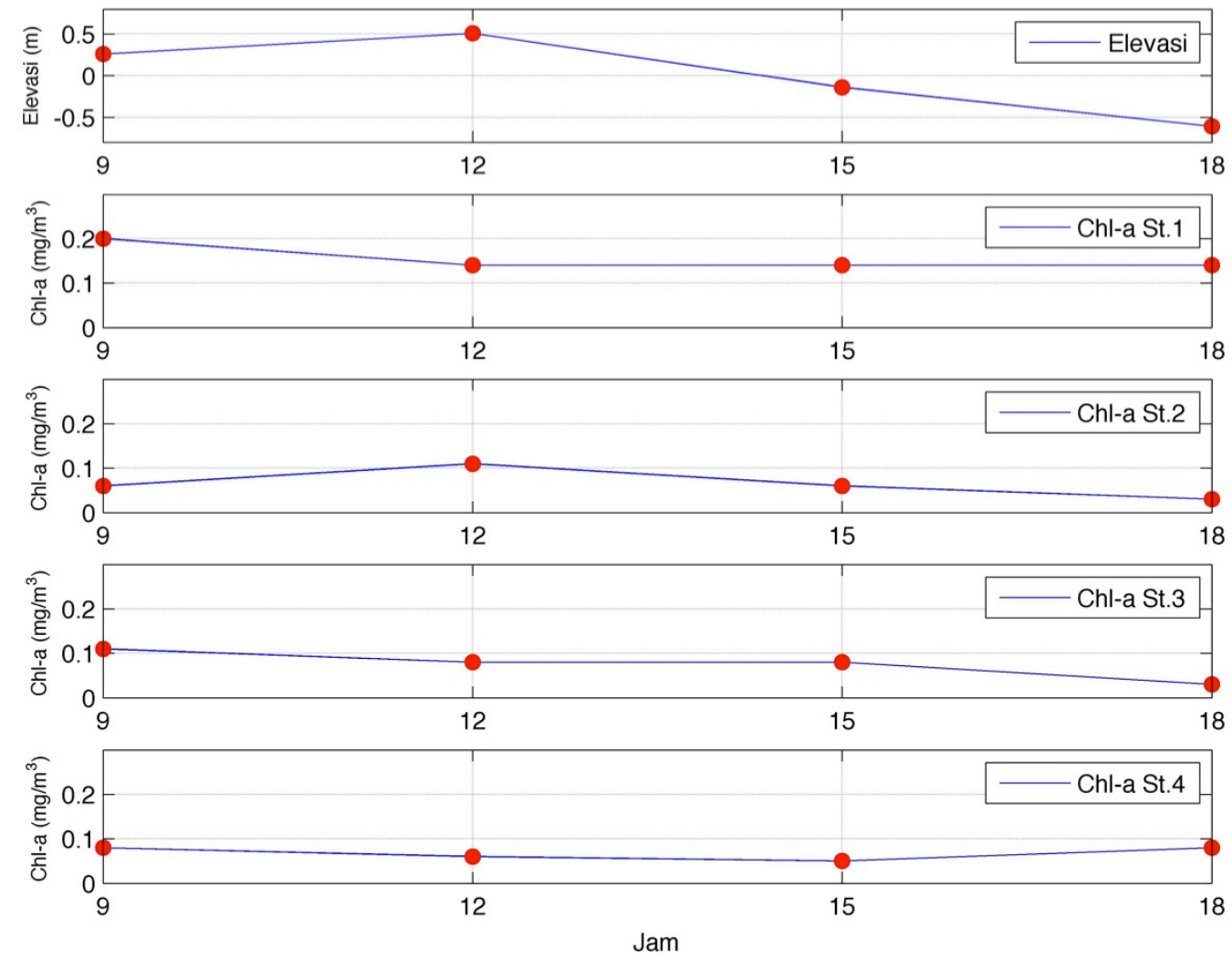

Gambar 20. Konsentrasi klorofil-a di Stasiun 1 - 4 Perairan Desa Musi Kabupaten Buleleng, Bali

\section{j. Populasi Bakteri Total}

Hasil analisis sampel air laut untuk populasi bakteri total (dalam koloni/mL) di 4 stasiun pengamatan dapat dilihat pada Tabel 11. Populasi tertinggi di Stasiun 1 adalah 4,1 x $10^{8}$ koloni/mL pada pukul 18.00 WITA. Sementara itu populasi tertinggi di Stasiun 2 adalah $6,6 \times 10^{9}$ koloni/mL, juga ditemukan pada pukul 18.00 WITA. Di Stasiun 3 dan 4, populasi tertinggi didapatkan pada pukul 09.00 WITA, dengan total populasi masing-masing 3,7 $\mathrm{x}$ $10^{4} \mathrm{koloni} / \mathrm{mL}$ dan $4,8 \times 10^{8} \mathrm{koloni} / \mathrm{mL}$.

Tabel 11. Populasi bakteri total di perairan Desa Musi Kabupaten Buleleng, Bali

\begin{tabular}{cccccc}
\hline \multirow{2}{*}{ Stasiun } & \multicolumn{3}{c}{ Waktu Pengamatan (WITA) } & \multirow{2}{*}{ Rata-Rata } \\
\cline { 2 - 5 } & 09.00 & 12.00 & 15.00 & 18.00 & \\
\hline Sta 1 & $3,7 \times 10^{4}$ & $4,7 \times 10^{5}$ & $1,3 \times 10^{5}$ & $4,1 \times 10^{8}$ & $1,03 \times 10^{8}$ \\
Sta 2 & $1,2 \times 10^{5}$ & $8,0 \times 10^{4}$ & $7,2 \times 10^{7}$ & $6,6 \times 10^{9}$ & $1,67 \times 10^{9}$ \\
Sta 3 & $3,7 \times 10^{4}$ & $3,2 \times 10^{4}$ & $3,1 \times 10^{4}$ & $3,4 \times 10^{4}$ & $3,35 \times 10^{4}$ \\
Sta 4 & $4,8 \times 10^{8}$ & $2,2 \times 10^{5}$ & $5,9 \times 10^{4}$ & $1,1 \times 10^{6}$ & $1,20 \times 10^{8}$ \\
\hline
\end{tabular}

Dari keempat stasiun tersebut dapat dilihat bahwa total populasi bakteri di Stasiun 3 adalah yang terkecil dengan fluktuasi yang kecil pula terhadap waktu, sedangkan di Stasiun 2 populasinya adalah yang terbanyak. Populasi di Stasiun 1 dan Stasiun 4 terlihat berada pada orde yang sama. 


\section{k. Konsentrasi Fosfat ( $\left.\mathrm{PO}_{4}-\mathrm{P}\right)$}

Fosfat merupakan salah satu nutrien utama yang dibutuhkan untuk pertumbuhan dan perkembangan fitoplankton di perairan (Wetzel, 1977). Konsentrasi fosfat di perairan sebagian besar berasal dari sisa-sisa limbah domestik dan pupuk yang memasuki perairan. Dari hasil pengukuran, dapat ditunjukkan bahwa kadar fosfat di perairan Desa Musi berada di kisaran $0,017 \mathrm{mg} / \mathrm{L}$ hingga $0,031 \mathrm{mg} / \mathrm{L}$ dengan konsentrasi rerata $0,02 \pm 0,004 \mathrm{mg} / \mathrm{L}$ (Gambar 21). Jika mengacu pada Kepmen LH Nomor 51 Tahun 2004, dimana baku mutu untuk fosfat adalah $0,015 \mathrm{mg} / \mathrm{L}$, maka konsentrasi fosfat di perairan Desa Musi sedikit berada di atas ambang batas. Besar dugaan lebih tingginya konsentrasi fosfat ini kemungkinan besar disebabkan oleh adanya kegiatan budidaya, pertanian dan juga limbah domestik. Merujuk pada klasifikasi kesuburan perairan berdasarkan konsentrasi fosfat, maka perairan Desa Musi secara umum termasuk ke dalam klasifikasi perairan mesotrofik, yaitu perairan yang memiliki konsentrasi fosfat dalam kisaran $0,011-0,300 \mathrm{mg} / \mathrm{L}$.
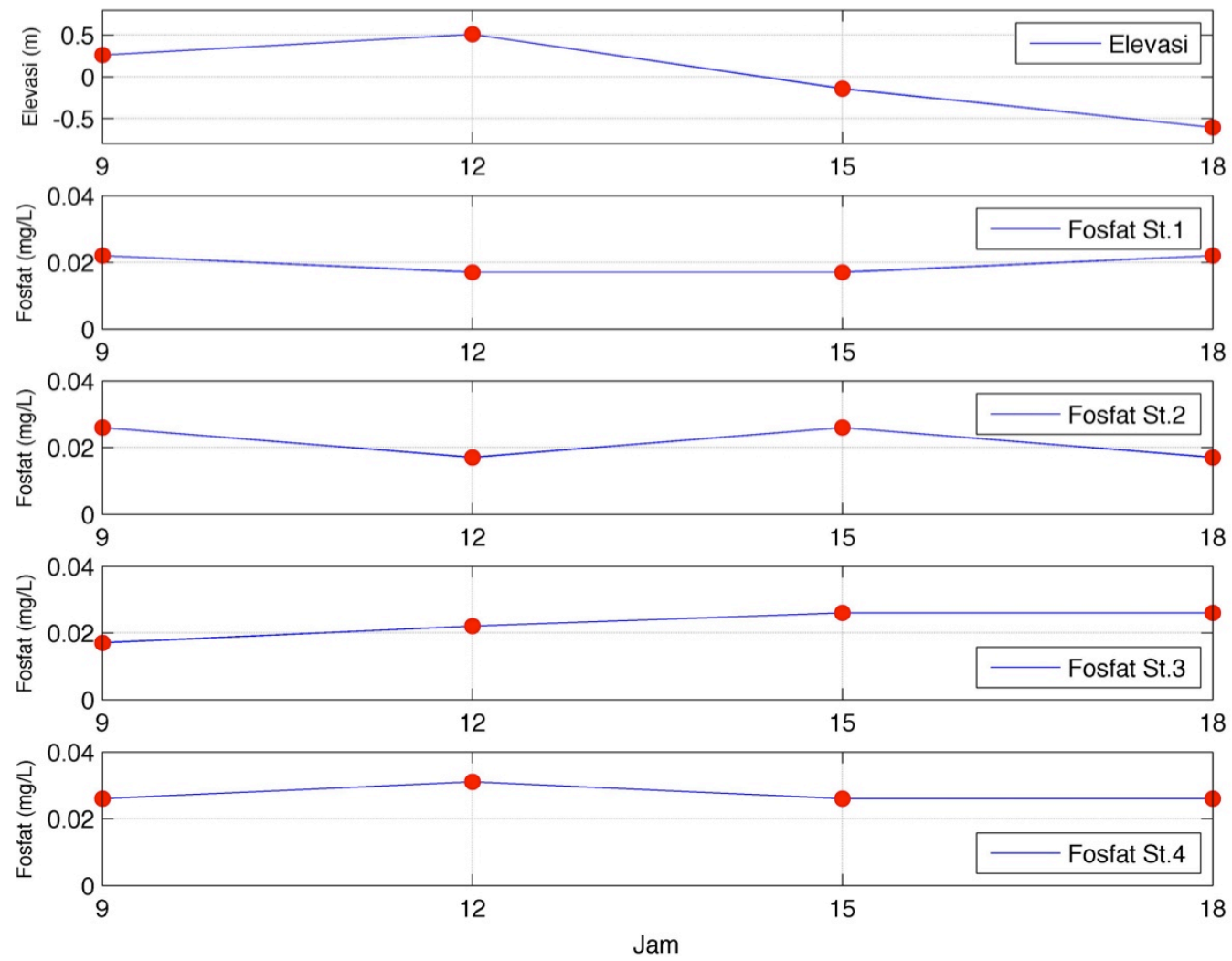

Gambar 21. Konsentrasi fosfat di Stasiun 1 - 4 Desa Musi, Kabupaten Buleleng, Bali 


\section{Konsentrasi Ammonia ( $\left.\mathrm{NH}_{3}-\mathrm{N}\right)$}

Dari pengukuran di 4 stasiun pengamatan didapatkan konsentrasi ammonia berada pada kisaran $<0,001 \mathrm{mg} / \mathrm{L}$ atau tidak terdeteksi hingga $0,033 \mathrm{mg} / \mathrm{L}$, dengan rerata $0,006 \pm 0,01$ mg/L (Gambar 22). Konsentrasi ammonia tertinggi didapatkan di Stasiun 4, dengan nilai maksimum mencapai $0,033 \mathrm{mg} / \mathrm{L}$ pada pukul 18.00 WITA. Sementara itu, konsentrasi ammonia di Stasiun 3 ditemukan sangat rendah, yaitu kurang dari 0,001 mg/L untuk setiap waktu pengambilan data. Secara garis besar, konsentrasi ammonia di Stasiun 1, 2 dan 4 pada saat pasang maksimum lebih rendah daripada saat menuju pasang. Kemudian konsentrasi kembali naik pada saat menuju surut. Dari kondisi menuju surut ke surut minimum, konsentrasi ammonia di Stasiun 1 dan 2 kembali berkurang, sementara di Stasiun 4 konsentrasinya justru naik dan konsentrasi ammonia di Stasiun 4 pada saat surut minimum jauh lebih besar daripada saat pasang maksimum.
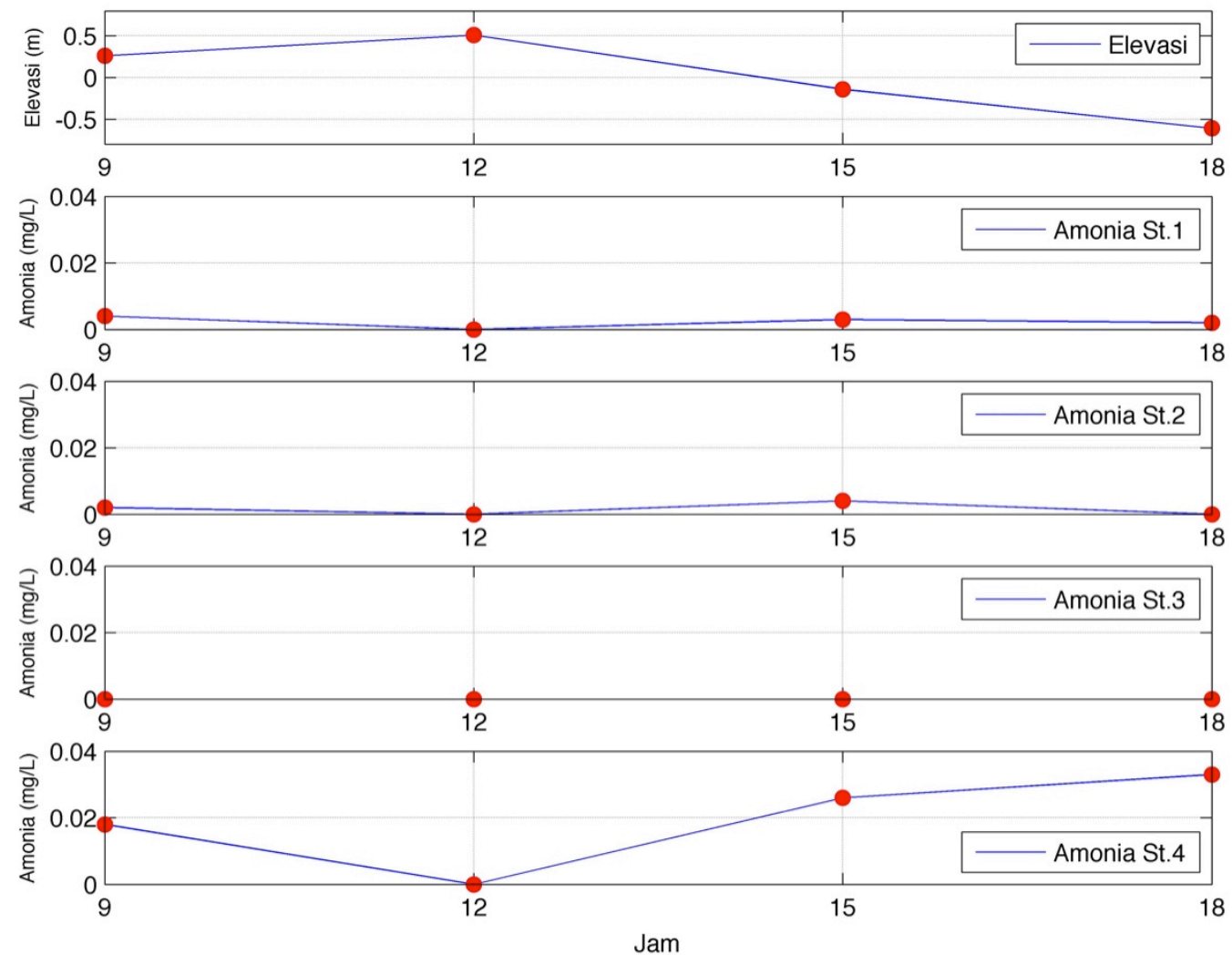

Gambar 22. Kadar Ammonia di Stasiun 1 - 4 Desa Musi, Kabupaten Buleleng, Bali

Konsentrasi ammonia di perairan alami umumnya bernilai kurang dari 0,1 mg/L (McNeely et al., 1979 dalam Effendi, 2003), sedangkan baku mutu ammonia untuk biota laut adalah 0,3 mg/L berdasarkan Kepmen LH No. 51 Tahun 2004. Berdasarkan pada acuan tersebut, maka dapat dikatakan bahwa konsentrasi ammonia di perairan Desa Musi masih jauh berada di bawah ambang batas. 


\section{m. Padatan Tersuspensi Total (Total Suspended Solid)}

Padatan tersuspensi merupakan padatan yang menyebabkan kekeruhan air, tidak terlarut dan tidak dapat mengendap. Padatan tersuspensi terdiri dari partikel-partikel dengan ukuran dan berat yang lebih kecil dibandingkan dengan sedimen seperti lumpur, biasanya dihasilkan dari kikisan tanah atau erosi tanah yang terbawa ke badan air. Jumlah padatan tersuspensi yang terlalu tinggi dalam perairan dapat mengurangi penetrasi sinar matahari ke dalam air sehingga dapat mengganggu proses fotosintesis fitoplankton. Selain itu, padatan tersuspensi juga dapat berpengaruh buruk terhadap pertumbuhan dan perkembangan zooplankton serta ikan (Setiawan et al., 2013).

Menurut Effendi (2013), padatan tersuspensi total (TSS) adalah bahan-bahan tersuspensi berdiameter $>1 \mu \mathrm{m}$ yang tertahan pada saringan millipore berdiameter pori $0,45 \mu \mathrm{m}$. Berdasarkan hasil pengukuran, nilai TSS di Stasiun $1-4$ memiliki nilai yang bervariasi. Nilai TSS yang diperoleh berkisar antara $1 \mathrm{mg} / \mathrm{L}$ hingga $17 \mathrm{mg} / \mathrm{L}$ dengan rerata 5,97 \pm $5,50 \mathrm{mg} / \mathrm{L}$ (Gambar 23). Nilai TSS tertinggi didapatkan di Stasiun 3 (17 mg/L pada pukul 09.00 WITA), namun nilainya cenderung menurun pada tiga waktu pengamatan selanjutnya, dan fenomena serupa juga dapat diamati pada Stasiun 2. Pada Stasiun 1 dan 4, nilai TSS baru mengalami peningkatan secara signifikan pada pukul 12.00 WITA (15 $\mathrm{mg} / \mathrm{L})$ dan 15.00 WITA (4 mg/L).

Jika dibandingkan dengan elevasi pasang surut pada saat pengambilan data (Gambar 23 panel paling atas), variasi TSS di Stasiun1 terlihat memiliki variasi yang mengikuti pasang surut tersebut. Pada saat pasang maksimum, TSS di Stasiun 1 juga maksimum, dan mengecil pada saat menuju surut hingga surut minimum. Hal yang berbeda terjadi di Stasiun 3, dimana pada saat pasang maksimum TSS-nya justru lebih kecil daripada saat surut minimum. Kondisi ini kemungkinan terjadi karena pada saat surut minimum, TSS dari arah pantai ikut terbawa hingga ke stasiun ini.

Menurut Kepmen LH No. 51 Tahun 2004, baku mutu TSS untuk biota laut di perairan karang disyaratkan tidak lebih dari $20 \mathrm{mg} / \mathrm{L}$. Berdasarkan acuan tersebut dapat disimpulkan bahwa nilai TSS di perairan Desa Musi tidak melebihi baku mutu pada saat dilakukan pengambilan data. 

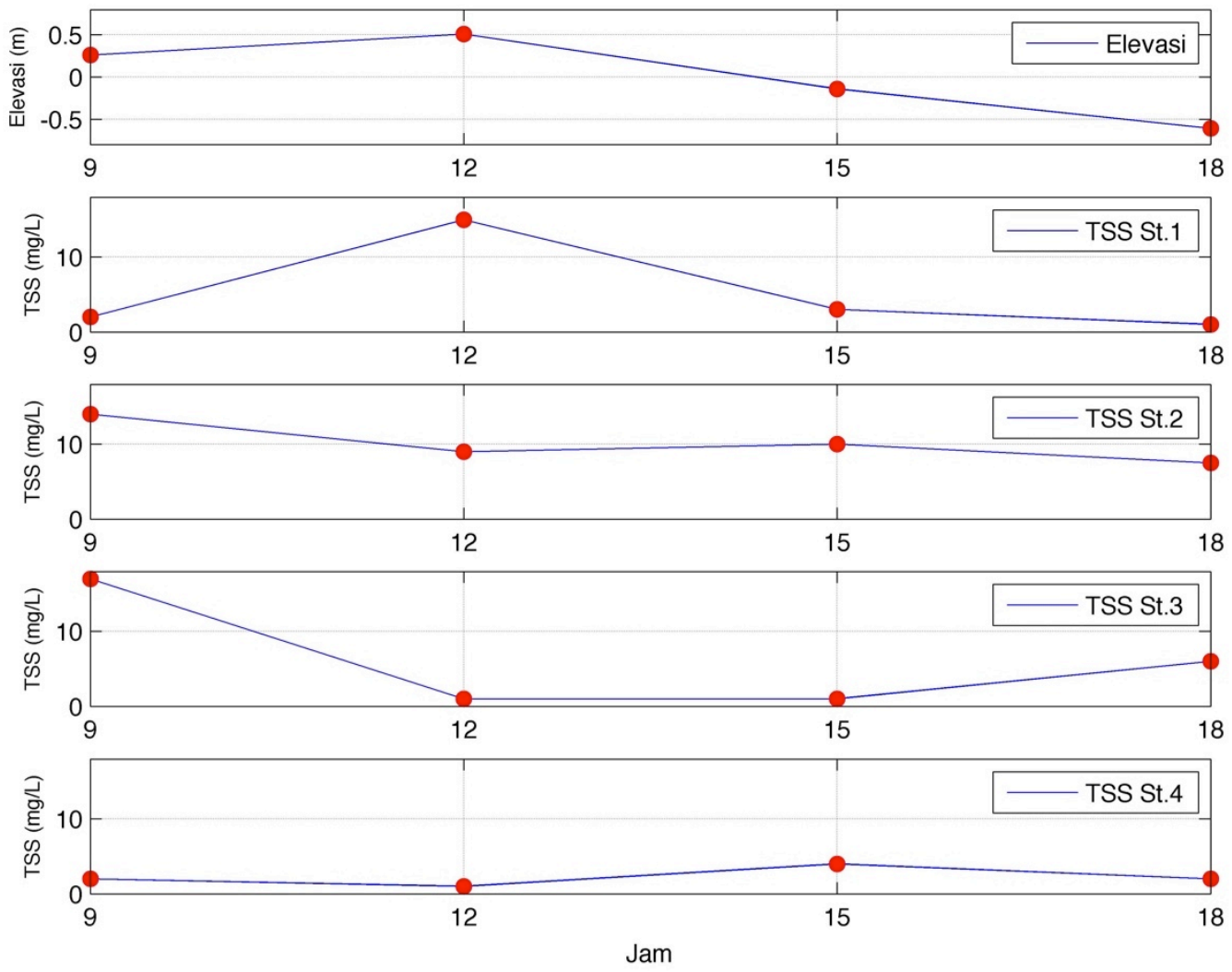

Gambar 23. Hasil pengukuran padatan tersuspensi total (TSS) di Stasiun $1-4$ Perairan Desa Musi, Kabupaten Buleleng, Bali

\section{n. Padatan Terlarut Total (Total Dissolved Solid)}

Padatan terlarut total (TDS) adalah bahan-bahan terlarut (berdiameter $<10^{-6} \mathrm{~mm}$ ) dan koloid (berdiameter $10^{-6} \mathrm{~mm}-10^{-3} \mathrm{~mm}$ ) yang berupa senyawa-senyawa kimia dan bahanbahan lain yang tidak tersaring pada kertas saring berdiameter 0,45 $\mu \mathrm{m}$ (Rao, 1992 dalam Effendi, 2003). Air laut memiliki nilai TDS yang tinggi karena banyak mengandung senyawa kimia, yang juga mengakibatkan tingginya nilai salinitas dan daya hantar listrik. TDS air laut umumnya terdiri dari bahan anorganik berupa ion-ion, contohnya ion $\mathrm{Na}+$, Ca2+, Mg2+, Cl- dan SO42-. Menurut McNeely et al., (1979) dalam Effendi (2003), nilai TDS yang berkisar di antara $10.001-100.000 \mathrm{mg} / \mathrm{L}$ memiliki tingkat salinitas asin (saline), sedangkan nilai TDS di atas $100.000 \mathrm{mg} / \mathrm{L}$ memiliki tingkat salinitas sangat asin (brine).

Nilai TDS pada 4 stasiun pengamatan pada saat pengambilan data memiliki kisaran antara $27.753 \mathrm{mg} / \mathrm{L}$ hingga $37.380 \mathrm{mg} / \mathrm{L}$ dengan rerata $33.149 \pm 3.131 \mathrm{mg} / \mathrm{L}$ (Gambar 24). Stasiun 2 memiliki nilai TDS tertinggi dibandingkan ketiga stasiun pengamatan lainnya (37.380 mg/L; 12.00 WITA), sedangkan nilai TDS terendah ditemukan pada Stasiun 4 
(27.753 mg/L; 15.00 WITA). Secara keseluruhan, saat dilakukannya pengambilan data nilai TDS di keempat stasiun pengamatan berada di tingkat salinitas asin (saline), yaitu masuk dalam kisaran $10.001-100.000 \mathrm{mg} / \mathrm{L}$.
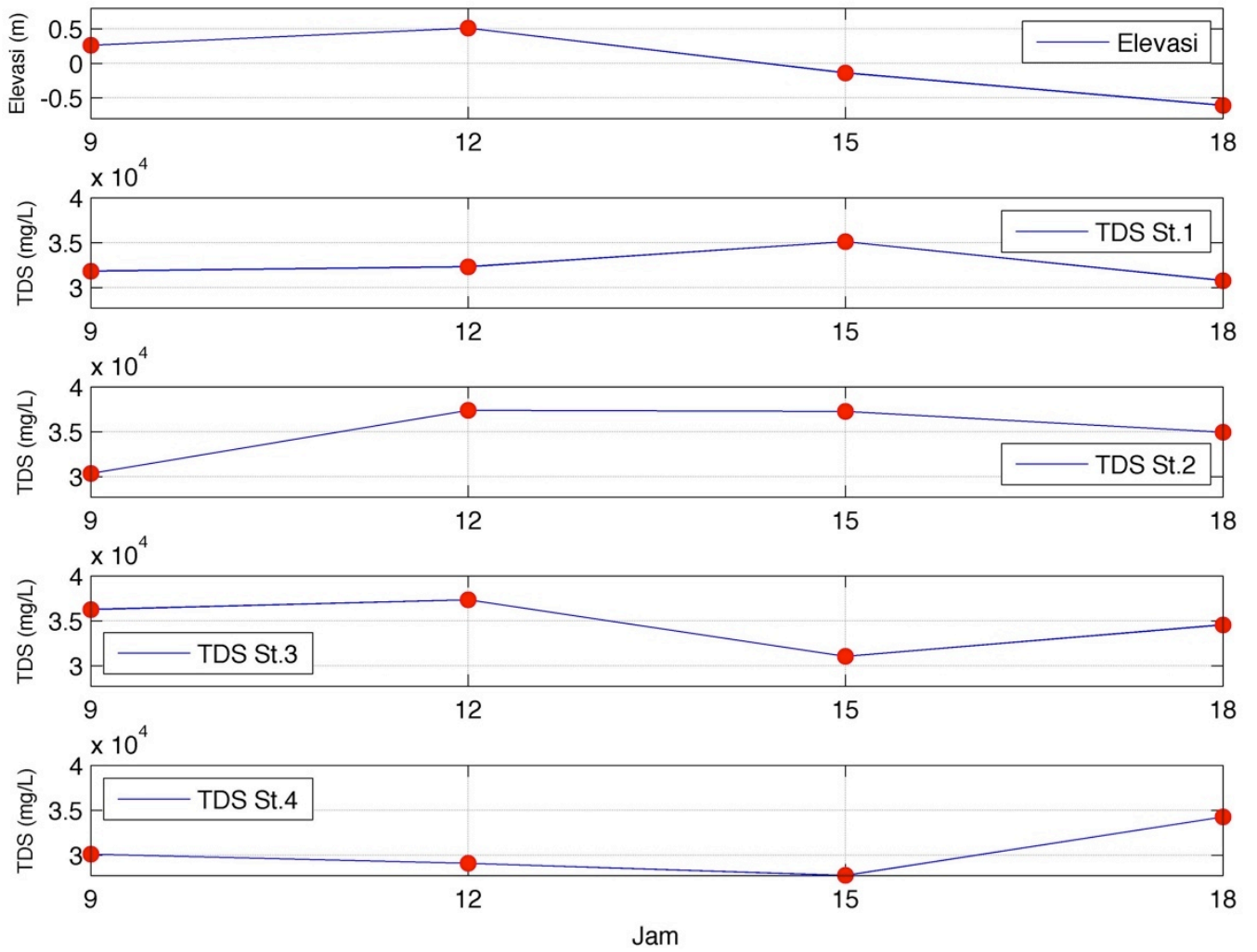

Gambar 24. Hasil pengukuran padatan terlarut total (TDS) di Stasiun 1 - 4 Perairan Desa Musi, Kabupaten Buleleng, Bali

\section{KESIMPULAN DAN SARAN}

Berdasarkan pada hasil survey yang telah dilakukan dan mengacu pada Kepmen LH No. 51 Tahun 2004 tentang Baku Mutu Air Laut, dapat disimpulkan bahwa perairan Desa Musi, Kabupaten Buleleng, Bali memiliki kualitas perairan yang masih berada di bawah ambang batas baku untuk biota laut. Dari hasil pengukuran insitu dan exitu yang dilakukan selama satu siklus pasang surut telah dapat diketahui karakteristik awal dari perairan ini yang dapat dijadikan acuan bagi perencanaan awal kegiatan budidaya laut oleh PT. Paramount Fishery Indonesia.

Karena kegiatan budidaya laut sangat sensitif terhadap perubahan kualitas lingkungan perairan, dan di lain pihak kegiatan budidaya laut juga memiliki potensi mengurangi kualitas lingkungan perairan, maka pemantauan secara berkala harus dilakukan untuk mengetahui perubahan yang terjadi setelah kegiatan budidaya dilaksanakan. Dengan demikian diharapkan kegiatan budidaya laut yang dilaksanakan akan tetap ramah lingkungan, dapat berkelanjutan, dan menghasilkan produk yang berkualitas tinggi. Dan sebaiknya pemantauan secara berkala ini dapat dilakukan setidaknya 6 bulan sekali. 


\section{DAFTAR PUSTAKA}

Effendi, H. 2003. Telaah Kualitas Air Bagi Pengelolaan Sumber Daya dan Lingkungan Perairan. Kanisius. Yogyakarta. 259 Hal.

Langkosono. 2007. Budidaya Ikan Kerapu (Serranidae) dan Kualitas Perairan. Neptunus (14) hal.61 - 67 .

Makmur, Assad, I.J., Utoyo, Mustafa, A., Hendrajat, E.A., Hasnawi. 2010. Karakteristik Kualitas Perairan Tambak di Kabupaten Pontianak. Prosiding Forum Inovasi Teknologi Akuakultur 2010. hal.1165 - 1171.

McNeely, R.N., et al. 1979. Water Quality Source Book, A guide to Water Quality Parameter. Inland Waters Directorate Water Quality Branch, Ottawa, Canada.

Menteri Negara Lingkungan Hidup. 2004. Surat Keputusan Menteri Negara Lingkungan Hidup Nomor 51 Tahun 2004 tentang Baku Mutu Air Laut untuk Biota Laut, Jakarta.

Rao, C. S. 1992. Environmental Pollution Control Engineering. Wiley Eastern Limited, New Delhi. 431 Hal.

Setiawan, A., N. Widagti, F. Hamzah, T. A. Wibawa, I. Triyulianti, S. C. Nugroho, dan N. D. Arisandi. 2013. Kondisi Kualitas Perairan Laut dan Produktivitas Estuarin dalam Mendukung Pengelolaan Perikanan Berbasis Ekosistem di Kabupaten Flores Timur. Balai Penelitian dan Observasi Laut, Bali. 57 Hal.

Wetzel, R.G. 1975. Limnology. W. B. Saunders Company. Philadelphia. 743 Hal. 


\section{BALAI PENELITIAN DAN OBSERVASI LAUT}

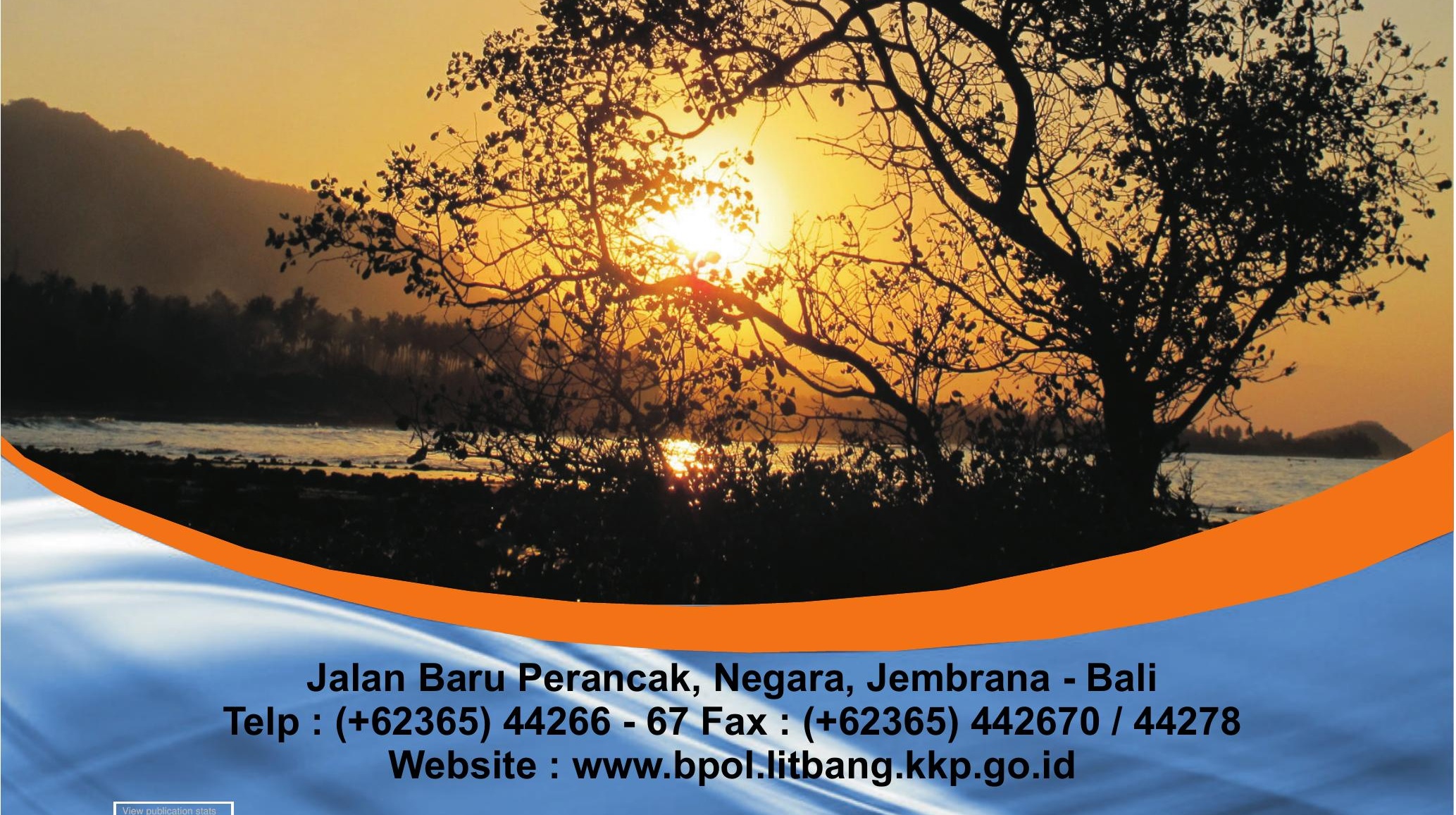

